\title{
QUALITY STANDARDS, INFORMATIVE LABELING, AND GRADE LABELING AS GUIDES TO CONSUMER BUYING
}

\author{
Card A. Auerbach* \\ I

\begin{abstract}
A Program for the Formulation and Use of Quality Standards, INFormative LabeliNg, and GRADE LABELING ${ }^{1}$
\end{abstract}

\section{A. Need for a Program}

We justify the American system of producing and distributing goods because we believe that it enables us to enjoy more goods, of better quality and at a cheaper price, than any other system yet devised, and because under it we, as consumers, by the choice we freely make in the market place, determine the kind, amount, quality, and price of what is produced. Basic to this justification is the assumption that we

* A.B. x935, Long Island University; LL.B. x938, Harvard University. Associatc Professor of Law, University of Wisconsin. Associate General Counsel, Office of Economic Stabilization, 1946; General Counsel, Office of Price Administration, r946-1947.

${ }^{1}$ I have relied heavily throughout this paper on the work done by Donald E. Montgomery in the course of the investigations of the Temporary National Economic Committec when Mr. Montgomery was Director, Consumers' Counsel Division, Department of Agriculture (see Hearings before the Temporary National Economic Committee, 76 th Cong., Ist Sess. (1939); id. pt. 8, Problems of the Consumer (1939); S. P. Kaidanovsxy and Alice L. Edwards, Consumer Standards (TNEC Monograph 24, 1941); Final Report of the Executive Secretarx to the TNEC, 77th Cong., Ist Sess. 379-339 (1941); Final. Report and Recommendations of THE TNEC, SEN. Doc. No. 35, 77th Cong., ist Scss. $439-452$ (1941)) and upon the excellent study by Gragg and Borden, Mervanandise Testing as a Guide to Consumer Buying (Business Research Studies No. 22, Harvard Graduate School of Business Administration, 1938).

This paper was provoked by Professor Ralph S. Brown's excellent article, Advertising and the Public Interest: Legal Protection of Trade Symbols, 57 YALE L. J. 1165 (1948). Professor Brown's proposed cure, not his diagnosis, fails to satisfy me because, in my opinion, even the adoption by the courts of his suggested approach to the law of trade symbols would not contribute materially to the solution of the problems which modern advertising poses for an economic order relying upon competition as a motive force.

Because the trade symbol is the vehicle of both informative and persuasive advertising, protection of the former, as Professor Brown recognizes, carries with it protection of the latter. But does this not give persuasive advertising all the protection it needs? In the main, the proposals which Professor Brown makes reinforce the stand which most courts have already taken in refusing to accept the dilution theory as a basis for extending the protection afforded against imitation of trade symbols. But is not persuasive advertising flourishing without such additional protection?

Furthermore, I doubt whether we can look forward to any significant restriction by the courts of the protection now afforded against imitation of trade symbols. The principal difficulty in the way of such a development is that it cannot be shown that the public will necessarily benefit by a policy of restriction. It is true that it is difficult for newcomers to enter many fields of business today because they lack the large amounts of money that must be spent on persuasive advertising if they are to compete successfully. But since it is by no means clear that new entrics under imitated trade symbols will serve the public interest, perhaps the courts, after all, are faced only with "private disputes among hucksters" in which the originator may have a better claim. Brown, supra, at 1167. Stork Restaurant, Inc. v. Sahati, I66 F. 2 d 348 (C. C. A. gth 1948), seems to be such a case.

These doubts should make us look elsewhere for additional aids to the solution of our problem. 
consumers have alternatives from which to choose, that we know what these alternatives are, and that our choice is made primarily by consideration of the price and quality of the various goods and services offered for sale. Only consumer preference exercised in this manner impels producers competing for the consumer's dollar to produce cheaper, better goods.

Whatever other arguments are advanced for or against the institution of brandname advertising as we know it, it seems clear that its primary purpose is not to inform the prospective purchaser about the price and quality of the article offered for sale. To the extent that advertising creates irrational consumer preferences, it negates one of the basic assumptions of our competitive system. Therefore, we must find other means of providing commodity information which will help consumers to buy more efficiently.

Much progress has been made in protecting the consumer against false and misleading information about the commodities he buys, but not enough has been done to require the disclosure of information which will enable the consumer intelligently to compare the products competing for his preference. Especially needed is comparative information about quality, without which price loses much of its meaning. By quality I mean primarily those characteristics of a product or a service which determine its performance and serviceability in meeting the need for which it is intended. ${ }^{2}$

\section{B. Elements of a Program}

A great amount of merchandise testing and evaluating is now being carried on by the Government, individual manufacturers and distributors, trade associations, technical and professional societies, and consumer groups. ${ }^{3}$ Except for the work done by consumer groups, surprisingly little of this effort reaches the consumer in a form that permits intelligent product comparison.

Gragg and Borden inform us that there are six steps in the comparative evaluation of the quality of products: $:^{4}(I)$ determining how many and what types

${ }^{2}$ One of the great difficulties in dealing with this subject matter is the lack of any commonly accepted nomenclature. In the main, I shall use the terminology employed by the Office of Price Administration for purposes of its work in this field. See OPA Administrative Order No. 49, September 3, 1942, National Archives. The consumer is also interested in the inherent physical and chemical properties of a commodity, which may be considered part of its "quality"-e.g., is a commodity made of silk or rayon, butter or oleomargarine? See GRAGG AND BoRDEN, op. cit. supra note I, at II. More information is presently available to the consumer about the physical and chemical properties of a commodity than about its serviceability.

${ }^{3}$ As of October, $x 94^{\circ}$, there were forty-six federal agencies concerned with the formulation and use of quality standards, most important of which were the Department of Agriculture, the National Bureau of Standards, and the Federal Trade Commission (Trade Practice Conferences). Some of the principal technical and professional societies doing standards work are the American Standards Association, the American Society for Testing Materials, the American Home Economics Association, the Society of Automotive Engineers, the American Institute of Electrical Engineers, and the Illuminating Engineering Socicty. Consumers' Union and Consumers' Research are the principal consumers' organizations testing and rating commodities. The activities of these private and governmental agencies are fully described in Kaidanovsky and Edwards, op. cit. supra note 1 . For results of the FTC Trade Practice Conferences, see FTC Trade Practice Rules, September I, 1935 to June 30, 1945 (1946).

- Gragg and Borden, op. cit. stupra note $\mathrm{I}$, at 9 . 
of products should be grouped together for the purpose of comparative evaluation; (2) deciding upon the criteria to use for judging worth; (3) defining the criteria in terms susceptible of measurement; ${ }^{5}(4)$ deciding how many and which units are to be examined; (5) making the measurements and classifying the units; ${ }^{\circ}$ and (6) translating the findings into forms usable by the consumer.

\section{Government Encouragement and Coordination of Technical Research}

Without sound technical research, meaningful and usable quality standards cannot be formulated. The present difficulty with technical research in this field is that the various organizations conducting it operate independently of each other and quite naturally do not produce uniform results. Unless there is uniformity, the results are of no help to the consumer trying to compare the worth of different commodities. Uniformity cannot be hoped for "unless criteria, sampling and test procedures are agreed upon in detail and unless the individuals making the tests are given common training and instruction." 7 Only a government agency (it might be a committee of all the interested government agencies, a separate Standards Board or the National Bureau of Standards) will be able to provide the necessary encouragement and coordination of technical research. This agency might be authorized to issue certificates to those testing laboratories which agreed to use the uniform criteria and procedures which it specified. This certificate would not be a condition of doing business, but laboratories which obtained it might be permitted to use it in the conduct of their business.

\section{Promulgation of Quality Standards by the Government in Forms Usable by the Consumer}

Many devices are currently employed to translate the technical findings of the research laboratories into forms usable by the consumer.

a. Informative labeling. The informative label is a marking or statement on the commodity itself, or, most often, on a label or tag attached to the commodity or its container, which passes on to the consumer test data about its quality, leaving consumers to draw their own conclusions as to the values to assign to the commodity. ${ }^{8}$ Labels or tags which carry instructions as to the effective use and care of

\footnotetext{
"These terms will be referred to as specifications. By "specification" is meant the description in measurable terms of one or more construction, content, or performance characteristics of a product. A specification may define or set forth two or more levels of quality, thereby defining grades or serics of the same product.

The term "standard" is often used interchangeably with "specification." It refers more broadly to any uniform measure of quality established by law or by general usage and consent. A standard may be expressed in the form of uniform specifications or methods of test or even in a simple definition of one important characteristic of the product.

"By "classification" is meant the listing of similar or related products into classes, groups, or grades for the purpose of defining or making clear the differences between the classes, groups, or grades. I have somewhat modified the Gragg and Borden presentation in order to use "classification" in this limited sense.

${ }^{7}$ GRAGG AND Borden, op. cit. supra note $\mathrm{I}$, at $\mathrm{I7}$.

${ }^{8} I d$. at 18 . Thus, for example, one large department store gives the following information regarding its muslin sheets and pillow-cases: "These sheets and pillow-cases are made from a good quality of cotton.
} 
the commodity are also included within the term "informative label."

For many reasons, informative labeling at present is inadequate as a guide to intelligent consumer buying. Producers and distributors follow no uniform practice regarding the amount of available information the label should carry or the terminology it should use. This makes it impossible for the consumer to compare the worth of similar products marketed by different sellers. Furthermore, in most cases only a technician will understand the information that is given. The ordinary consumer, and that includes most of us, will not comprehend the label, even if, as is also unlikely, it is read carefully.

b. Grade labeling. A "grade label" is a marking on the commodity itself, or on a tag or label attached to the commodity or its container, of a phrase or symbol which implies a qualitative judgment of relative inferiority or superiority in a graduated scale. Thus, for example, a large food chain presently grades certain canned goods which it sells under its brand name, "Grade A," "Grade B," or "Grade C." Information explaining the differences between the grades may accompany the grade notation or the notation may stand alone.

To the consumer, grade labeling is much more helpful than informative labeling because the grade notation in and of itself represents a qualitative judgment by which purchase may be guided. At present the difficulty is that it reflects the judgment of the producer or distributor himself. The consumer is safely guided by the grade notation in selecting among the products sold by the same seller, but no basis is afforded for comparison with the products sold by others.

c. Certifications of quality. Many products bear notations certifying that they meet certain standards of quality specified by the certifying organization. The value of these certifications to the consumer depends upon the reliability of the certifying organization. This type of certification can be and has been subject to abuse. ${ }^{10}$ In any event, it too, affords no basis for comparative product evaluation.

To enable the consumer to compare competing products, informative and grade labeling and certifications of quality must be based on commonly accepted quality standards that reflect the uniform results of agreed methods of technical research. In addition, informative labeling requires agreement on the amount of information that will be furnished and on the terminology that will be used. These objectives cannot be achieved without government action. Since the conveying of understand-

They conform to the following specifications: Construction of cloth-warp 68; filling. 72; equals: I 49 threads to the square inch. Breaking strength-Not less than 70 pounds in the warp and filling direction. Shrinkage-Warp not more than 5 per cent-filling not more than $2 \frac{1}{2}$ per cent. Weight-Not less than 4.6 ounces per square yard. They also meet our specifications for precision of size and quality of workmanship."

${ }^{\circ}$ For example, the same department store conveys the following information on a tag: "Attention. Cotton stockings are less elastic than silk. They must be laundered with special care. Use mild soap and water. Shape gently and hang to dry. Never hang them in hot sun or over a radiator. Do not iron ... it weakens the fibers." These informative labels are sometimes referred to as "caution tags."

${ }^{10}$ See $\$ \mathrm{I}_{4}(\mathrm{~d})$ (4) of the Lanham Act, 60 STAT. 433, 15 U. S. C. $\$ 1064(d)(4)(1946)$, which is intended to remedy some of these abuses. 
able information about the comparative worth of commodities requires a balancing of the interests of producers, distributors, and consumers, it is primarily a regulatory, not a technical, problem. It is suggested, therefore, that this part of the program be entrusted to the Federal Trade Commission, which now deals with this type of problem at its Trade Practice Conferences. The Federal Trade Commission, too, is the logical agency to enforce any parts of the program which are made legally enforceable.

d. Voluntary and mandatory aspects of suggested program. It is not part of the suggested program to prohibit a manufacturer from producing or selling any kind of product. ${ }^{11}$ It is proposed, in the interest of the consumer and the competitive system, that the Government assume responsibility for seeing to it that to the extent possible comparative evaluations are made of the quality of the commodities that are actually produced and the results made known to consumers so that they can be guided thereby.

It is not suggested that the Government proceed immediately by law to impose mandatory labeling in accordance with government-promulgated quality standards on all goods and services offered for sale. That would be foolish. It is contemplated that if the responsible government agency concludes that adequate technical research has been done to permit intelligent formulation of quality standards for a particular product, it should, with the cooperation of all parties concerned, formulate the standards and promulgate them as official government standards. Furthermore, the Government should announce the kind of informative or grade labeling that will most appropriately tell the consumer about the official standards. Use of the standards and labeling should be voluntary, but sellers who employ them should be permitted to tell prospective buyers that they are doing so. In return, these sellers should be held accountable for the accuracy with which their product is graded and labeled. Inaccuracy might be designated an unfair competitive practice against which the Federal Trade Commission, or a competitor, could proceed. In some cases, only minimum specifications of quality might be formulated for a product and a government certification offered to all sellers meeting them. In other cases, quality grades might be feasible, accompanied by informative or even grade labeling. Mandatory government standards accompanied by government-approved methods of labeling should come only after a reasonable trial period of successful voluntary use.

I do not wish to rest my case on each and every one of these more detailed suggestions. There may be other and better ways of effectuating the main purpose, which is to give consumers as much factual, rational guidance in buying as is possible. At this point, I wish to say only that if the Government accepts responsibility for the program, considering the technical resources already available and the

\footnotetext{
12 Failure to distinguish between the formulation and use of quality standards and a simplification program is responsible for much confusion. Simplification secks to concentrate production upon the most essential types, sizes, grades, colors, and packagings of products, and upon the more cssential and serviceable features of the product itself. Simplification was a wartime measure necessary to conserve labor and materials.
} 
wartime experience of the Office of Price Administration, consumers can be given much more helpful guidance than is now supposed.

II

\section{OPA Experuence with the Formulation and Use of Quality Standards, Informative Labeling, aNd Grade Labeling}

There has been considerable consumer agitation for a program similar to that suggested. ${ }^{12}$ This section will relate only the OPA experience. In dealing with this historical material, I am mindful of what Morris R. Cohen once said:

As a rule it will be found that the historical introduction is very much like the chaplain's prayer which opens a legislative session or political convention; very little of the subsequent proceedings are decided by reference to it. ${ }^{13}$

I feel some necessity, therefore, to justify the historical account that follows.

The OPA experience is presented mainly in order to give others interested in the general problem easier access to the valuable materials in the OPA files, now reposing in the National Archives. Moreover, OPA contributed to the advance of knowledge in this field. In those areas of business in which buyers and sellers, even prior to OPA, were accustomed to use quality standards in buying and selling, OPA sharpened and refined the terminology employed. In many areas, OPA for the first time described commodities in terms of quality standards or specifications. The OPA experience will be helpful, too, in determining how many and what types of commodities ought to be grouped together for the purpose of comparative evaluation. OPA's work will be valuable, also, to those interested in translating quality variations into appropriate price differentials. And finally, wartime price control provided another interesting arena for the continuing debate between the proponents and opponents of the use of official quality standards and labeling.

\section{A. Wartime Concern with the Formulation and Use of Quality Standards, Informative Labeling, and Grade Labeling}

OPA did not make use of quality standards, informative labeling, and grade labeling because it thought these measures desirable in themselves, but because they were found necessary to effective price control. In the first place, it was recognized that the true price of a commodity would increase not only if its dollar price was raised but also if its quality was deteriorated, the dollar price remaining the same. ${ }^{14}$

\footnotetext{
12 For notes on history prior to OPA, see INTERIM REPORT OF THE SPECIAL SUbCommitTeE on INVESTTgation of Restrictions on Brand NAmes and Newsprint of the Commitiee on Interstate and Foretgn Commerce, H. R. Rep. No. 808, 78 th Cong., rst Sess. 33 (1943). This report will hereafter be referred to as the Boren Committe Report; S. C. Oppenheim, Cases on Unfair Competition 447450, particularly 450-45I n. I62 (I948); TNEC materials, supra note $I$.

${ }^{23}$ Morris R. Cohen, Reason and Nature 370 (r932).

${ }^{14}$ The importance of effective quality control was underscored by the fact that the Bureau of Labor Statistics' cost of living index did not completely reflect the hidden price inflation resulting from quality deterioration. An Appraisal of the United States Bureau of Labor Statistics Cost of Living Index by a Special Committee of the American Statistical Association 9 (1943). Responsibility to the people required that this hidden inflation be combated.
} 
Secondly, it was found that the fixing of uniform dollar-and-cents maximum prices for the particular commodity was the most effective of all the pricing techniques, because it was most easily understood by sellers and buyers and easiest of enforcement. ${ }^{15}$ This technique required a careful description of the commodity to which the dollar-and-cents price was intended to apply. ${ }^{16}$ The use of standards and specifications, accompanied by informative or grade labeling, helped to accomplish both these objectives. ${ }^{17}$ As Price Administrator Prentiss M. Brown explained:

Where Office of Price Administration uses minimum standards, it uses them to describe and classify the commodities for which maximum prices are established. The Office of Price Administration order then provides that a particular article must meet the minimum specifications if it is to command the particular ceiling price. Office of Price Administration regulations do not prohibit a manufacturer from producing an article which does not meet these minimum specifications. But the manufacturer would be required to sell the article at a lower price. Neither do Office of Price Administration regulations prevent a manufacturer from making an article of better quality than the standards describe. Standards are thus used by Office of Price Administration with two purposes, both of which are essential for effective price control. One purpose is the adequate description of the article for which a ceiling price is established. This is necessary to avoid confusion among buyers and sellers as well as to create a sound basis for compliance and for enforcement. Many commodities are customarily bought and sold on minimum standards or specifications. The other purpose is to protect consumers against deterioration of guality or serviceability, without corresponding price reduction, which is plainly a disguised form of price inflation. ${ }^{18}$

Quality deterioration was also a rationing problem. A rationing coupon promised more than a given quantity of goods. Impliedly, it promised that the goods obtained with it would be able to satisfy certain needs for a certain length of time. To keep this promise, however, required the exercise of powers which only the War Production Board, and not OPA, had, for it required that goods (shoes, for example) of a certain minimum quality actually be produced and not merely that a shoe of inferior quality take a lower maximum price.

The interest of the war production agencies in the effort to combat quality deterioration was likewise real, for the production of shoddy commodities wasted labor and materials and made it more difficult to assure an adequate civilian supply of goods in the face of increasing employment of resources for war purposes. On the

${ }^{15}$ For a discussion of the various pricing techniques used by OPA, see Proslems in Price Controz: Pracing Techniques (Historical Reports on War Administration: Office of Price Administration, General Publication No. 8, i947); Standardization and Simplification, Manual of Price Contror 265-279 (I943).

18 "Without such standards, the Administrator would have been forced either to adopt a complieated formula or "freeze" type regulation for each commodity in an attempt to make cciling prices reflect customary grade differences or, instead, to ignore such differences and set some average price for the commodity which would have been too high for some low-grade articles and too low for those of superior quality." Office of Price Administration, .Seventh Quarterly Report for the Period Ended Sẹtember 30, I943 21 (1944).

${ }_{17}$ This objective was also sought, to be accomplished in regulations which did not use uniform dollar-and-cents maximum prices. For examples, see Appendix A.

${ }^{18} 89$ Cong. Rec. 681I (1943). 
other hand, the war production agencies had an interest in seeing to it that OPA did not insist too rigidly that the consumer continue to get precisely the same quality commodity for the maximum price, lest the elimination of "frills" and the substitution of more plentiful for less plentiful materials be discouraged. What was required was a program that would discourage continued production of nonessential features of a commodity at the same time that essential quality features were rigidly maintained.

\section{B. Wartime Organization for Effectuating Program}

The administrative organization evolved during the war for the work on quality standards and simplification split responsibility for the two different, yet related, objectives of the program-effective price control and increased production. At the very beginning of the war effort, the achievement of these objectives was entrusted to the Consumer Division of the Advisory Commission to the Council of National Defense. ${ }^{19}$ When the Office of Price Administration and Civilian Supply was established on April II, I94x, ${ }^{20}$ it combined the functions of the Price Stabilization and Consumer Divisions of the Advisory Commission and was expressly directed to "'formulate programs designed to assure adequate standards for, and the most effective use of, consumer goods. . .."21 The Office of Production Management, established January 7 , I941, ${ }^{22}$ was entrusted with the task of increasing production for the national defense. This division of responsibility proved to be unsatisfactory because both agencies had production authority over the same industries, though for different purposes; ${ }^{23}$ and so the civilian supply functions of OPACS were transferred to OPM. ${ }^{24}$ Thereby responsibility for the production and price-control objectives of the quality standards and simplification program was divided. The Office of Price Administration succeeded OPACS, but was invested with pricecontrol authority only. ${ }^{25}$ This division of responsibility was continued with the enactment of the Emergency Price Control Act of $1942^{26}$ and the creation of the War Production Board. ${ }^{27}$

${ }^{10}$ The Council of National Defense was composed of the Secretaries of War, Navy, Agriculture, Commerce, and Labor, and was appointed by the President pursuant to the Act of August 29, 1916, 39 STat. 649. Under authority of this Act, the President, on May 29, 1940, appointed the Advisory Commission to the Council of National Defense, consisting of seven commissioners, heading Transportation, Agriculture, Consumer, Price Stabilization, Labor, Industrial Production and Industrial Materials Divisions, 5 F. R. 2II4, 238I (I940). The Office for Emergency Management, directed by one of the administrative assistants to the President, maintained liaison between the President and the Council and its Advisory Commission. Administrative Order, May 25, 1940, 5 F. R. 2109 (1940). The Office for Emergency Management, in turn, was part of the Executive Office of the President, established Sept. II, I939, by Exec. Order No. 8248,4 F. R. 3864 (1939).

${ }^{30}$ Exec. Order No. 8734,6 F. R. 19I7 (I94I). OPACS continued to be part of the OEM.

${ }^{31} I d . \$_{2}(\mathrm{~g})$.

${ }^{32}$ Exec. Order No. 8629, 6 F. R. IgI (I94I). OPM, too, was part of OEM.

${ }^{23}$ For a discussion of this problem, see The Role of the Office of Civilian Requirements I-33 (Historical Reports on War Administration: War Production Board. Special Study No. 20, 1946).

${ }^{24}$ Exec. Order No. 8875, 6 F. R. 4483 (1941). ${ }^{25}$ lbid.

${ }^{30} 56$ StAт. 23 (1942), as amended, 50 U. S. C. App. $\$ \$ 901-946$ (1946).

${ }^{27}$ Exec. Order No. 9024, 7 F. R. 329 (1942). See also Exec. Order No. 9040, 7 F. R. 527 (1942), defining additional duties and functions of the WPB, and Exec. Order No. 9125, 7 F. R. 2719 (1942) defining additional functions, duties, and powers of the WPB and the OPA. 
Eventually, the Office of Economic Stabilization ${ }^{2 s}$ and the Office of War Mobilization and Reconversion ${ }^{29}$ were given the task of coordinating the activities of OPA and WPB. But this came late in the day and both these offices were, in the main, ineffective in this field. This resulted, in my opinion, in the failure adequately to achieve either of the objectives of a wartime program of simplification and quality standards. ${ }^{30}$

The task of formulating quality standards for consumer goods for use in OPA regulations was first entrusted to a Standards Branch within the Consumer Division of the General Services Department, which was headed by a Deputy Administrator of the OPA. ${ }^{31}$ On September 3, 1942 , this branch was established as a Standards Division under the supervision of the Deputy Administrator in charge of general services. $^{32}$ The Standards Division, headed by a director, was composed of three branches: a Consumer Commodity Branch, an Industrial Commodity Branch, and a Testing Branch. This division was assigned the job of helping to achieve both the price-control and production objectives of the standardization and simplification program. It had no authority, however, to act on its own. So far as the production objective was concerned, it could only make recommendations to the WPB. As for the price-control objective, it was in a better position. Though it was not authorized to prepare any standards or labeling orders for official promulgation, and could only make recommendations to the operating divisions of OPA, it was not an "outside" agency. It could always appeal over the heads of the operating divisions to the Administrator of the OPA, and this right was recognized. ${ }^{33}$

On September 27, 1943, the Standards Division was transferred to the Price Department, headed by the Deputy Administrator for Price. ${ }^{34}$ Its functions and dutics remained the same. Some time in 1944 , the Standards Division itself was abolished, but a standards officer was retained on the staff of the Deputy Administrator for Price. $^{35}$

As of May 10, I943, when the activity of the Standards Division was at its height, the division had a total of sixty-three employees, including clerical and

${ }^{28}$ Stabilization Act of 1942, 56 Stat. 765 (1942), 50 U. S. C. App. \$\$961-971 (1946); Excc. Ordcr No. 9250,8 F. R. $787 \mathrm{r}$ (1942).

${ }^{20}$ War Mobilization and Reconversion Act of 1944, 58 STAT. 785 (1944), 50 U. S. C. App. \$165I (1946).

${ }^{30}$ For a full discussion of this problem, see Problems in Price Control: Changing Production PATterns I-104 (Historical Reports on War Administration: Office of Price Administration, General Publication No. 9 1947).

31 Office of Price Administration, First Quarterly Report for the Pertod Ended April 30 , 194270 (1942).

${ }^{22}$ OPA Administrative Order No. 49, National Archives. For major provisions of this order, see Appendix B.

${ }^{33}$ OPA Operating Order No. 4, September 3, 1942, National Archives.

st OPA Administrative Order No. 67 (revised), National Archives. For a general discussion of the organization of the OPA Price Department and its relation to the other operating departments of OPA, see Problems in Price Control: National Office Organization and Management (Historical Reports on War Administration: Office of Price Administration, General Publication No. 12 1947).

${ }^{\mathrm{sE}} I d$. at 53 . 
stenographic help. ${ }^{36}$ After it was abolished, only the standards officer and one assistant spent full time on standards work. But the number of employees in the Standards Division does not represent all the manpower devoted to this task, because the operating personnel in the Price Department were also concerned with the problem.

\section{Basis of OPA's Authority to Effectuate Program}

OPA's authority to tie quality standards to the ceiling prices established for a commodity and to require informative and grade labeling was based on Sections 2(a), 2(c), 2(d) and 2(g) of the Emergency Price Control Act of I942. Section 2(a) contained the basic grant of authority to establish maximum prices to prevent inflation. Section 2(c) authorized the Administrator to make such classifications and differentiations in a regulation as in his judgment were necessary or proper in order to effectuate the purposes of the Act. Section 2(d) authorized the Administrator "to regulate or prohibit speculative or manipulative practices (including practices relating to changes in form or quality) ... in connection with any commodity ..." which in his judgment were equivalent to or likely to result in price increases inconsistent with the purposes of the Act. Section $2(\mathrm{~g})$ authorized the Administrator to make such provisions in his regulations as he deemed necessary to prevent their circumvention or evasion.

The principal limitations on the Price Administrator's powers in this field were contained in Sections $2(h)$ and $2(j)$ of the Act. Section $2(h)$, as amended, prohibited the Administrator from using his powers "to compel changes in the business practices, cost practices or methods, or means or aids to distribution, established in any industry ... except where such action is affirmatively found by the Administrator to be necessary to prevent circumvention or evasion" of the regulation. Section 2(j), the so-called Taft Amendment, was the most important provision in the Act for our present purposes and will be considered in some greater detail. ${ }^{37}$

D. Legislative History of Section $2(j)$ (the Taft Amendment) of the Price Control Act

Congressional attention was first directed to OPA's activities in formulating quality standards for consumer goods and requiring informative and grade labeling by businessmen complaining of specific regulations which affected them. On February 3, I943, Congressman Halleck of Indiana introduced H. R. $98, \mathbf{3 8}$ to direct the Committee on Interstate and Foreign Commerce to conduct an investigation to determine:

\footnotetext{
${ }^{30}$ Hearings before the Subconmittee of the House Committee on Appropriations on the National War Agencies Appropriation Bill for 1944, 78th Cong., Ist Sess. pt 2, 148 (1943).

${ }^{37}$ In Thomas Paper Stock Co. v. Porter, 328 U. S. 50 (1946), the Supreme Court took the view that Section $2(j)$ was, in effect, merely a particularization of the limitations already imposed by Section $2(h)$. For cases applying Section $2(\mathrm{~h})$ in other situations, see Philadelphia Coke Co. v. Bowles, 139 F. $2 d$ 349 (E. C. A. 1943), and Seaboard Oil Co. v. Bowles, I49 F. 2d 66I (E. C. A. 1945).

${ }^{38} 89$ Cong. Rec. 565 (1943).
} 
(I) Whether the War Production Board, the Office of Price Administration, or any other agency or officer in the executive branch of the Government, has formulated or is formulating plans with a view to putting into effect (a) requirements with respect to Federal grade labeling of articles or commodities, and the discarding of private brand names of articles or commodities; or (b) any other requirements intended to bring about simplification and standardization of production, marketing, and distribution of articles or commodities, as well as concentration of industry or production; and

(2) Whether, and to what extent, the formulation and carrying out of such plans are necessary in connection with the war effort; and

(3) The extent to which any such plans may represent an attempt to change our domestic economy along lines not authorized by Congress. ${ }^{39}$

The Rules Committee reported this resolution with an amendment not pertinent to our present inquiry. ${ }^{40}$ 'The resolution as amended was agreed to. ${ }^{41}$

The Committee on 'Interstate and Foreign Commerce appointed a subcommittee headed by Congressman Lyle $\mathrm{H}$. Boren of Oklahoma to conduct the investigation called for by H. R. 98. The Boren Committee, as it soon came to be called, met frequently during May and June of $1943 .{ }^{42}$ It concentrated its attention on a proposed OPA regulation for knitted underwear which was never issued, the OPA women's rayon hosiery regulation, ${ }^{43}$ which was the center of controversy, and the OPA regulation on canned goods. ${ }^{44}$ Spokesmen for the Underwear Institute, the National Association of Hosiery Manufacturers, the National Retail Dry Goods Association, the Grocery Manufacturers of America, the National-American Wholesale Grocers Association, the National Canners' Association, and the Association of National Advertisers informed the committee that their organizations strongly opposed what the OPA had done or was proposing to do in these regulations. There was little public support for the OPA program from business quarters.

The Boren Committee did not formally report to Congress until October 27, I943, ${ }^{45}$ by which time the Taft Amendment had become law. Nevertheless, the

${ }^{39} \mathrm{Id}$. at 551 .

${ }^{40}$ H. R. Rep. No. 30I, 78 th Cong., Ist Sess. (1943). The amendment broadened the inquiry to include an investigation to determine whether "requirements [were being imposed] which would have the effect of curtailing the production or consumption of newsprint or book papers used in the printing of newspapers, magazines, or such other publications as are admitted to second-class mailing privileges." (1943).

4189 Cong. Rec. 3258 (1943). For the debate on the resolution, see 89 Conc. Rec. 3245-3258

12 Hearings before a Subcommittee of the Committee on Interstate and Foreign Commerce, Pursuann to H. R. Res. 98,78 th Cong., Ist Sess. pts. I and 2 (1943). These hearings will be referred to as the Boren :Committee Hearings. See also Hearings before the Subcommittee on Complaints of the Senate Special Committee to Study and Survey Prablems of Small Business Enterprises, 78th Cong., Ist Sess. pt. 22 (1943), which are also concerned with this problem.

${ }^{4}$ Maximum Price Regulation 339 (Women's Rayon Hosiery) originally issucd March 8, 1943, cffective May 15, 1943, 8 F. R. 2930, 3215, 4922, 6049, 9521, and 9839 (1943). See Revised Maximum Price Regulation 339, issued and effective August 23, 1943, 8 F. R. II74I (I943), and Sccond Revised Maximum Price Regulation 339, issued and cffective January 4, 1944. 9 F. R: 207 (1944). The committee also considered MPR 208 (Staple Work Clothing), 7 F. R. 6649, 8940, 8948, and 10015, 8 F. R. 4887, and RMPR 304 (Specified Utility Shirts), issued September 4, 1943, 8 F. R. 1063 (1943).

"MPR" 306 (Certain Packaged Food Products), issued and effective January 22, 1943, 8 F. R. 1114, $66 \mathrm{I7}, \mathrm{rog} 86$ (1943).

45 Boren Committee Report, op. cit. supra note 12. 
Committee's work was primarily responsible for that amendment as well as for the interim action taken by Congress.

The first blow aimed by Congress at the OPA program was the provision, contained in the Appropriation Act for OPA for the fiscal year ending June $30,1944{ }^{46}$ that " ... no part of this appropriation shall be used for the promulgation or enforcement of orders requiring grade labeling or standardization of food products, wearing apparel or other processed or manufactured commodities or articles." It is a fair inference from the debates on the floor of the House and Senate that the precise effect of this proviso was not understood in either house.

Nevertheless its language of prohibition was sweeping, and Price Administrátor Prentiss M. Brown turned for assistance to his former colleagues on the Senate Banking and Currency Committee. The committee was then considering House Joint Resolution ${ }^{4} 47$, to extend the life of the Commodity Credit Corporation, which had already passed the House. ${ }^{47}$ It responded to the pleas of the Price Administrator, and in reporting $\mathrm{H}$. J. Res. $\mathrm{I}_{47}$ to the Senate ${ }^{48}$ it added provisions repealing the proviso in the appropriation bill and substituting the Price Administrator's proposal. ${ }^{49}$ The committee explained that the Price Administrator "fears that the [appropriation bill] proviso will nullify his price-fixing system as to many commodities where the pricing is based on certain specifications and standards," and that the committee proposal would authorize the Administrator to require standardization when "no practicable alternative exists for securing effective price control with respect to such commodity." Senator Taft offered a floor amendment ${ }^{51}$ to the committee proposal,

40 57 STAT. 522, 526. This proviso was offered as an amendment from the floor to the appropriation bill, H. R. 2968, by Congressman Andresen of Minnesota. 89 Cong. R'Ec. 6127 (1943). It passed the House on June $18,1943,89$ Cong. Rec. 6127 (1943). The Senate Committee on Appropriations recommended deletion of this amendment. SEN. REP. No. 367,78 th Cong., Ist Sess. 2 (1943). But the Senate rejected this recommendation. 89 Cong. Rec. 6811-6812 (1943). And so the proviso remained in the bill as it passed the Senate. 89 ConG. Rec. 6839 (1943). The Conference Committee, then, did not deal with it. Conference Rep. 662, 89 Cong. REc. 7135 (I943). For further explanation in the House of the Andresen amendment, see 89 Covg. Rec. 7r40, 7I4I (I943). The appropriation bill became law July $12,1943$.

${ }^{17} 89$ Cong. Rec 7065 (1943).

${ }^{48}$ SEn. ReP. No. 387,78 th Cong., rśt Sess. (1943). The Report was submitted by Senator Wagner on behalf of himself and Senator Taft. Although the appropriation bill had not yet become law when the Senate Banking and Currency Committee reported on July 3, 1943 (89 Cong. REc. 7117), both the Senate and the House had already passed the Andresen rider to the appropriation bill and it was known that it would eventually become law. The committee did not have time to hold hearings on the Price Administrator's proposal.

${ }^{10}$ The Price Administrator's proposal was for a new Section 2(j) to the Price Control Act which would have provided that nothing in the Act should be construed:

" $(x)$ as authorizing the elimination of trade and brand names; (2) as authorizing the Administrator to require the grade labeling of any commodity; or (3) as authorizing the Administrator to standardize any commodity, unless the Administrator shall determine, with respect to such standardization, that no practicable alternative exists for securing effective price control with respect to such commodity; but no order of the Administrator shall be deemed to require standardization because it fixes maximum prices for different kinds, classes, or types of a commodity which are described in terms of specifications or standards, if such specifications or standards were, prior to such order, in substantial use in the trade or industry affected, or have been established by another Government agency." 89 CoNG. REC. 725 I (I943).

${ }^{50}$ Sen. Rep. No. 387 , supra note 48 , at 213 . The committee went on to say that "it is also made clear that there is no objection to basing a price system on the classification of commodities if such classification was in substantial use in the trade or industry affected, or has becn established by some other Government agency."

E1 89 CoNG. REc. 725 I (I943). 
which ultimately became Section 2(j) of the Price Control Act. 52 The Taft Amendment provided that nothing in that Act should be construed:

(I) as authorizing the elimination or any restriction of the use of trade and brand names; (2) as authorizing the Administrator to require the grade labeling of any commodity; (3) as authorizing the Administrator to standardize any commodity, unless the Administrator shall determine, with respect to such standardization, that no practicable alternative exists for securing effective price control with respect to such commodity; or (4) as authorizing any order of the Administrator fixing maximum prices for different kinds, classes, or types of a commodity which are described in terms of specifications or standards, unless such specifications or standards were, prior to such order, in general use in the trade or industry affected, or have previously been promulgated and their use lawfully required by another Government agency.

Senator Taft explained that "the amendment as I now offer it is only slightly different from the committee amendment. The Price Administrator regards it as a distinct improvement for his purposes over the language of the appropriation bill, and it meets with the agreement of all the trades which have been directly interested." 53

\section{E. Effect of the Taft Amendment}

Immediately after the enactment of the Taft Amendment, each operating branch of OPA's Price Department was directed to review every regulation in its field to determine whether it met the requirements of that amendment. To guide review, an official statement, Price Policy Statement No. 4, was issued, interpreting the new Section $2(j) .^{54}$ This statement was based on a memorandum written by Henry M. Hart, Jr., then Associate General Counsel of the OPA, which carefully analyzed the legislative history of Section $2(\mathrm{j}) .^{\mathbf{5 j}}$

With regard to the first clause of Section $2(j)$, Mr. Hart explained that "no OPA regulation has ever sought to eliminate or restrict the use of established trade or brand names. Provisions designed to regulate the evasive practice of changing brand names in order to take advantage of looser pricing methods applicable to new commodities, have, however, been under consideration. The Taft amendment will make it impossible to forbid such evasive changing of brand names."

With regard to the second clause, Mr. Hart distinguished grade labeling, prohibited by the Taft Amendment, and descriptive (informative) labeling, which remained permissible, and formulated the definition of grade labeling used in this paper. ${ }^{56}$

${ }^{32} 56$ STAT. 24 (1942), as amended, 60 STAT. 670, 50 U. S. C. App. $\$ 902(j)$ (1946).

5389 CoNG. REc. 725I (1943). The purpose of Taft's modification of the committee amendinent seems to have been to prevent the claim that pricing by reference to types of standards, other than those specified in clause 4, would not be "standardizing" and hence would not be subject to the limitations in clause 3. For the further legislative history of the Taft Amendment, see 89 Conc. Rec. 7252; Conference Rep. No. 697, 89 Conc. Rec. 7444, 7498, 7499 (1943); Statement of the President upon signing the bill, July $x 6$, r943, Pike AND Fischer OPA Service $35: 52,55$.

${ }^{6}$ OPA Price Policy Statement No. 4, July 22, I943; see also OPA Price Operating Instructions, National Office Nos. 15 and 16 , July 29, x943. National Archives.

${ }^{5}$ Effect of the Taft Amendment to the Emergency Price Control Act of 1942, Memorandum from Henry M. Hart, Jr. to Prentiss M. Brown, Price Administrator (July I6, 1943). National Archives.

so "Thus the requirement that denier and gauge be marked on hosiery is descriptive labeling. So also is the requirement that used articles be marked 'as is' or 'reconditioned' or that 'scconds' or 'irregulars' 
The most perplexing problem of interpretation concerned the relationship between the third and fourth clauses of Section 2(j). As Mr. Hart put it, "Does the requirement of clause 4 that the Administrator make use of standards already established by industry usage or government order have the effect of preventing him from exercising the authority recognized in clause 3 to standardize commodities, not thus previously standardized, when he finds that such action is essential to effective price control?"57 Mr. Hart's answer was no, on the ground that an affirmative answer would reduce clause 3 to an absurdity. "Clause 4 would then say that the Administrator may make use of standards only in the case of commodities already standardized. The authority to standardize recognized in clause 3 would be meaningless. Power to act would be denied to the Administrator in the very cases in which he is asked to inquire whether action is essential to price control and in spite of his determination that it is." ${ }^{\text {s8 }} \mathrm{Mr}$. Hart therefore concluded that to "standardize" a commodity within the meaning of clause 3 meant to base ceiling prices "upon standards or specifications which were not previously established either by general industry usage or by the action of another agency." To base ceiling prices upon standards or specifications which were so established was not to standardize. 69

On the basis of the Hart Memorandum, Price Policy Statement No. 4 instructed the operating divisions of OPA that

A regulation in which prices are based on, or calculated by reference to, standards or specifications is valid if any one of the following conditions is met:

(a) The standards or specifications were, prior to their use in the regulation, in general use in the industry;

(b) The use of the standards or specifications was, prior to their use in the regulation, lawfully required by another government agency;

(c) The Administrator has determined that no practicable alternative exists for securing effective price control.

In the light of the Hart Memorandum and Price Policy Statement No. 4, each operating branch of OPA reviewed the regulations in its field. In those cases in which a finding could be made that the regulation complied with either clause 3 or clause 4 of the Taft Amendment, the branch amended the preamble of the regu-

be so marked where these are not parts of a system of graduated classification but merely indicate manufacturing imperfections ... Grade labeling is also to be distinguished from marking which is designed to indieate not degrees of superiority for the same use but different uses, and which implies no comparative judgment of quality or serviceability. Thus, the marking of No. 8 , No. 10, and No. 12 fishhooks as such would not constitute grade labeling." Hart Memorandum, supra note 55, at 3.

"7z Hart Memorandum, stipra note 55, at 5. The Boren Committee briefly discussed whether "the prohibition in the fourth clause of the Taft amendment is independent as suggested in the report of the conference committec, or is qualified by the third clause," and concluded that further Congressional clarification might become necessary, although at one point it expressed an opinion contrary to that of Mr. Hart. Boren Commirte Report, supra note 12, at 7, 44 .

${ }^{68}$ Hart Memorandum, supra note 55, at 6 . It was acknowledged that "compliance with the exception in clause 3 will not justify action in violation of clause 1 or 2."

${ }^{50}$ Id. at 4 . 
lation to add a finding of compliance. The amendment was accompanied by a Supplementary Statement of Considerations justifying the finding.

The work of the operating branches culminated in a series of seventeen supplementary orders. ${ }^{80}$ To accompany these supplementary orders, the Price Administrator issued a Statement of Considerations explaining and justifying his interpretation of the Taft Amendment. ${ }^{61}$ In all, 246 regulations covered by these supplementary orders were found to use standards and specifications in aid of price control in such a way as to comply with the requirements of the Taft Amendment. Of these, I6o used standards and specifications which were in general use in the trade or industry affected prior to their use by OPA. Standards and specifications in five other regulations were found to have been previously promulgated and their use lawfully required by another government agency. In the case of twenty regulations, an alternative finding was made that the standards or specifications used were either in general use in the trade or industry affected or had been previously promulgated and their use lawfully required by another government agency. With regard to five regulations, it was found that the standards and specifications used were both in general use in the trade or.industry affected and had been previously promulgated and their use lawfully required by another government agency. In the case of fifty-six regulations, the Administrator found that no practicable alternative to the use of standards and specifications existed for securing effective price control. $^{62}$

\footnotetext{
${ }^{80}$ Supplementary Order No. 55 (Grocery Products and Tobacco), 8 F. R. 12550 (1943); SO 56 (Grains and Fertilizers), ibid; SO 57 (Dairy and Poultry Products), id. at 12551; SO 58 (Petroleum Products, Asphalt and Asphalt Products), id. at 12552; SO 59 (Consumer Durable Goods), ibid; SO 60 (Building Materials), ibid; SO 6I (Logs, Lumber, and Lumber Products), ibid; SO 62 (Iron and Steel), id. at 12553; SO 63 (Meat and Meat Products), ibid; SO 64 (Paper, Paper Products, Raw Materials for Paper and Paper Products, Printing and Publishing), id. at 12554; SO 65 (Apparel), id. at 12554; SO 66 (Nonferrous Metals), id. at 12554; SO 67 (Chemicals and Drugs), id. at 12555; SO 68 (Rubber and Rubber Products), id. at 22555 ; SO 69 (Leather, Wol, and Miscellaneous Fiber Products), id. at 12556; SO 70 (Machinery and Transportation Equipment), id. at 12556; SO 71 (Cotton and Synthetic Textiles and Textile Products), id. at 12556. All of these orders were issued and became effective September I I, 1943. See Appendix C for a breakdown of the regulations covered by these Supplementary Orders in accordance with the applicable authorizing provision of the Taft Amendment.

${ }^{61}$ Statement of Considerations Accompanying Supplementary Order No. 55, September I1, 1943, Pike and Fischer OPA Service 35:52. The Supreme Court sustained the Administrator's interpretation of the Taft Amendment but held that the regulations covered by the supplementary orders were invalid from July 16, 1943, when the Taft Amendment became law, until September II, 1943, when the supplementary orders were issued and became effective. Thomas Paper Stock Co. v. Porter, 328 U. S. 50 (1946), reversing Thomas Paper Stock Co. v. Bowles, 15I F. 2d 345 (E. C. A. 1945) on issue of validity between July $\mathrm{I} 6$ and September II, x943, but sustaining Thomas Paper Stock Co. v. Bowles, I48 F. $2 d 83$ I (E. C. A. 1945), which upheld Administrator's interpretation; see Avon Western Corporation v. Bowles, I45 F. 2 d 473 (E. C. A. I944); United States v. Pepper Bros., I42 F. 2d 340 (C. C. A. 3d 1944); Ambrosia Brewing Co. v. Bowles, I47 F. 2d 550 (E. C. A. r944).

62 Unfortunately, these supplementary orders do not embody all the regulations reflecting OPA activity in the field under study. In the first place, they reflect the situation as of September 11,1943 , and not subsequent thereto. Secondly, it is doubtful whether, even as of that date, all official action taken because of the Taft Amendment was embodied in these supplementary orders. As of September 30, 1943, 444 price regulations were in effect. Of these, 261 contained standards provisions: 167 contained standards which were in general use in the trade prior to their use by OPA, 32 contained standards legally required by another government agency, and the remaining 62 regulations containcd standards
} 
I have been unable to find any case in which OPA used standards or specifications in a regulation and determined that it could not make a finding bringing the regulation into compliance with the Taft Amendment. However, as a result of the Taft Amendment, grade labeling requirements were removed from twenty regulations covering meats, eggs, poultry, butter, canned fruits and vegetables, rubber heels, antifreeze, rayon hosiery, and certain lumber, paper, and other products. ${ }^{63}$

\section{F. Further Limitation of OPA Authority}

In I944, the Congress imposed an additional restriction on OPA's authority to tie quality standards to maximum price regulations covering processed fruits and vegetables. A rider to the Second Deficiency Appropriation Act, I944, ${ }^{64}$ provided that "none of the funds appropriated in this Act shall be used to pay the salary or expenses of any person fixing maximum prices for different kinds, classes, or types of processed fruits and vegetables which are described in terms of specifications or standards, unless such specifications or standards were, prior to such order, in general use." The purpose of this proviso was to prohibit OPA from pricing canned fruits and vegetables on the basis of the grades formulated by the Agricultural Marketing Administration. This prohibition remained in the Appropriation Acts for the remainder of the life of the price control program. ${ }^{65}$

which were necessary, in the judgment of the Price Administrator, because no practicable alternative existed for effective price control. Seventh QuARTERLY Rieport of THE OPA For Period ENDED SEPTEMBER 30, r943 20 (1943). Some of the more significant regulations not included are: MPR 339 (Women's Rayon Hosiery) and subsequent revisions of that regulation, RMPR 304 (Specified. Utility Shirts), and MPR 306 (Certain Packed Food Products), stipra notes 43 and 44. To wade through all of the OPA regulations looking for those which raised questions under the Taft Amendment is a very discouraging task. The regulations covered by the supplementary orders are, however, adequate to give a very good picture of the nature of OPA's work in this field.

${ }^{\circ}$ SeVenth Quarterly Report, supra note 62, at 19.

o4 58 Stat. 547, Pub. L. No. 375, 78th Cong., 2d Sess. (June 28, 1944). For legislative history of this proviso, see Hearings before the Subcommittee of the House Committee on Appropriations on the Second Deficiency Appropriation Bill for 1944, 78th Cong., 2d Sess. 306-309, 3II-312, 32I-324, 344-349 (1944); Hearings before the Subcommittee of the Senate Committee on Appropriations on $H$. $R$. 5040, 78th Cong,, 2d Sess. 22, 26-39 (1944). As reported by the House Committee, H. R. 5040 proscribed any use of standards or specifications by the OPA in any regulation unless they were previously in general use. H. R. Rep. No. 1660, 78th Cong., 2d Sess. 7 (1944). For debate in the House, see 90 Cong. Rec. 6095-6098 (1944). The House passed the bill containing this provision. 9o Cong. REc. 6099 (1944). In reporting H. R. 5040 the Senate committee recommended the limited proviso which ultimately became law. SEN. Rep. No. 1028, 78th Cong., 2d Sess. 2 (r944). For debate in the Senate, see 90 Cong. Rec. $6463-6468$ (1944). The Senate struck out this limited proviso, 90 Cong. Rec. 6468 (1944). The Conference Committee recommended that the limited proviso be restored. Conference REp. 1745, 78th Cong., 2d Sess. 2 (r944). The Senate accepted the recommendations of the Conference Committee without. debate, 90 Cong. Rec. 6640 (1944), as did the House, 9o Cong. Rec. 667I (1944).

${ }^{\circ}$ First Deficiency Appropriation Act, 1945, Pub. L. No. 40, 79th Cong., Ist Sess. (April 25, 1945), 59 Stat. 77, 79; Second Deficiency Appropriation Act, r945, Pub. L. No. 132, 79th Cong., Ist Sess. (July 5, 1945), 59 STAт. 412, 416; Third Deficiency Appropriation Act, 1946, Pub. L. No. 521, 79th Cong, 2d Sess. (July 23, 1946), 60 Sтат. 600, 6ro. 
IV

Evaluation of Principal Objections to Suggested Program

A. The Program Is Impractical

Men whose plants during the war were placarded with the typically American slogan, "The Impossible We Do Immediately-the Miraculous Takes a Little Longer," apparently did not find it incongruous to argue that the formulation of a program for the use of quality standards and grade labeling was just not possible. There is no point in minimizing the difficulties, which have been stated and analyzed admirably by Gragg and Borden. Merchandise testing to date is by no means a science. Consumer tastes and preferences do vary widely. A product that is best for one purpose may not be best for another. Even if a grading system can be worked out by which one commodity is rated better than another, it still does not by itself tell the consumer how much better so that the respective prices can be evaluated. And the problems of translating the results of technical research into a language consumers will understand are very real. But I cannot help agreeing with the over-all judgment on this issue of practicality expressed by Donald Montgomery:

The task is extensive, but not overwhelming. Compared with the accomplishments of applied science in the development of production techniques, it is relatively simple. Not lack of ability, but lack of interest, seems to be the cue for failure of our cconomy thus far to adopt appropriate methods for transferring the products of industry into consumer hands-lack of interest on the part of vendors who find it easier to deal with uninformed consumers; lack of interest on the part of governments which to date haye recognized few specific obligations to serve consumer welfare; and lack of interest among consumers themselves. ${ }^{86}$

Much of the argument about practicality will be less heated and less dogmatic when we turn to the possibilities offered in specific commodity fields and actually try to realize them. Let us take meats as an example. I realize that experience with this commodity is no indication of what can be done in the non-food field. But let us see what can be done today with regard to meats which is not being done.

During the war, OPA fixed maximum prices for beef, veal, lamb, and mutton carcasses and wholesale cuts on the basis of the quality grades promulgated by the Department of Agriculture. ${ }^{b 7}$ The following grades were specified for beef carcasses and wholesale cuts: choice, good, commercial, utility, and cutter and canner. Grades specified for veal, lamb, and mutton carcasses and wholesale cuts were choice, good, commercial, utility, and cull. In each case, the grade had to be determined according to specifications worked out by the Department of Agriculture. ${ }^{68}$

${ }^{\circ 8}$ Final Report of the Executtve Seleretary to tHe TNEC, 326-327, 77th Cong., Ist Sess. (1941).

${ }^{67}$ RMPR 169, RMPR 239, Appendix C, infra. For OPA action on quality standards for other meats, see RMPR 148, MPR 336, MPR 389, MPR 398, ibid.

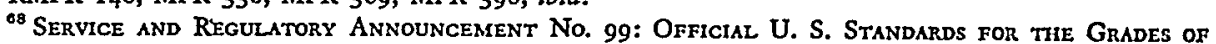
Carcass Beef (U. S. Dep't of Agric., Food Distribution Adm'n, issued as amended May, 1942); Service aNd Regulatory Announcement No. it4: Officiat. U. S. Standards for the Grades of Veal and Calf Carcasses (U. S. Dep't of Agric., Food Distribution Adm'n, issued as amended October, 1940); Service and Regulatory Announcemsent No. 123: Official U. S. Standards for tue Grades of 
The actual grading was required to be done by official graders of the Department of Agriculture, governed by rules issued by the Department. ${ }^{69}$ If an official grader was not available, the slaughterer was authorized to do his own grading, but according to the same rules. If a nonofficial grader did the grading, he was required to place a stamp on the carcass (with a harmless marking fluid conforming to a formula approved by the Bureau of Animal Industry in the Department of Agriculture and set out in the regulation) marking the grade letter "AA" for choice grade of beef, veal, or lamb carcass; " $A$ " for good grade; " $B$ " for commercial grade; " $C$ " for utility grade; " $D$ " for cutter and canner grade of beef and for cull grade of veal; " $\mathrm{C}$ " for cull grade of lamb. The following grade letters were required for yearling: "A" for choice, "B" for good, and "C" for commercial, utility, and cull. For mutton, the grade letters were " $S$ " for choice and good, " $M$ " for commercial, and " $R$ " for utility and cull. If an official grader did the grading, he was authorized to substitute for the grade letters the name of the grade itself, "choice" or "good" as the case might be, preceded, if he wished, by "U. S." If yearling or mutton was graded officially, the words "yearling" or "mutton" also had to be stamped on the carcass.

The grade designation had to be so stamped on the carcass that it would appear on each retail cut made therefrom. The retailer was prohibited from removing the grade designation. In addition, he was required to separate the meat in his showcase according to grade and to designate the grade so that his customers could see and read it. ${ }^{70}$

This system continued as long as meat prices remained under control. When the Taft Amendment forced the OPA to eliminate the grade labeling features of the system, the Economic Stabilization Director restored them. ${ }^{71}$ The housewife became throughly familiar with the grade letters. Even the Boren Committee reported, two months after the Economic Stabilization Director acted, that "no opposition against this system of grading and labeling of meat was voiced at any time in testimony before the subcommittee."72 Many retail stores still label the

Lamb Carcasses, Yearling, Mutron, and Mutron Carkasses (U. S. Dep't of Agric., Food Distribution Adm'n, March, I93I). OPA did not follow Department of Agriculture grades precisely. Thus, for example, "choice" in all cases was designated as the top grade, though the Department of Agriculture recognizes a better grade, "prime."

${ }^{\circ}$ Service and Regulatory Announcement No. 98 (revised): Rules and Regulattons of the Secretary of Agriculture Governing the Grading and Certification of Meats, Prepared Meats, Meat Food Products, and Meat By-Products, for Class, Quality (Grade) and Condition (U. $S$. Dep't of Agric., Food Distribution Adm'n, issued as amended September 26, 1942).

${ }^{70}$ MPR' 355, 394, Appendix C, infra.

${ }^{71}$ Office of Economic Stabilization Regulation No. I, issued and effective August 5, 1943, 8 F. R. 10988 (1943); Statement of Reasons for OES Regulation No. I, Pixe and Fischer OPA Service 41 :61; Delegation of Authority in Respect to Meats, issued and effective September 14, 1943, 8 F. R. 12669 (1943). The Taft Amendment expressly limited only the powers of the Price Administrator; the authority of the Economic Stabilization Director remained unaffected. Blalack v. United States, 154 F. 2d 591 (C. C. A. 6th 1946), cert. denied, 329 U. S. 738 (1946), rehearing denied, 329 U. S. 828 (1946). OES Regulation No. I was the only case in which the Economic Stabilization Director sought to impose his authority directly upon business. Otherwise, he exercised authority through directives to other government agencies.

${ }^{72}$ Bonen Committee Report, supra note 12 , at 36. 
grades of meat, but in many all trace of this system has disappeared. Yet is there any good reason why this system should not be continued in peacetime? ${ }^{\text {th }}$

There were relatively few regulations in which OPA used grade labeling. More numerous were the regulations in which all sellers were required to use uniform informative labeling. ${ }^{74}$ This type of labeling was not attacked by the Boren Committee or the Taft Amendment. It can be helpful to consumers even in peacetime.

Fragmentary as these examples are, they do indicate that no purpose is served by trying to pass an over-all judgment on the practicality of formulating quality standards and using uniform informative and grade labeling. Each commodity presents its own problems. Stylized commodities will, of course, present the most difficulties, but even in this case there is no reason why the consumer should not be told the quality of the material used and construction employed, so that it will be known that the seller is asking to be paid for style. In short, the important thing is to agree that the program suggested is worth while and that it ought to be put into operation. Only then will obstacles which seem insuperable now be viewed in their proper size and practical steps taken to overcome them.

\section{B. The Program Will Eliminate Brand Names and Brand-Name Advertising}

The deep emotion with which this argument is made is revealed by the eloquent denunciation of the OPA program requiring grade labeling of the I943 pea crop which was made in a letter to Congressman Halleck from a person the Congressman did not name: $:^{75}$

Grade labeling is the opening gun of as sinister a move as could well be figured by the bureaucrats, to despoil our internal economy for the benefit of the Socialist system of production for use and not for profit.

Grade labeling the 1943 pea crop is only the beginning. Brought down to its logical end product, through the inevitability of gradualness, step by step, would come the disappearance of advertising and hence of a free radio and a free press; mass unemployment, in the absence of competition; degrading of product, without brand guarantee; and monopoly cartelizing, destroying the independent merchant. Yes; it goes even further than these immediate probable results, for it would put the eggs all in one basket for the take-over by the totalitarian state.

Somewhat more temperately, the spokesman for the Association of National Advertisers charged that ". . . it seems to be proposed to substitute a system of Government grading for the free, competitive system of trade-marked goods which

${ }^{73}$ The OPA experience also showed the practicality of grade labeling of cggs, MPR 333; poultry, RMPR 269; butter, MPR 289; and canned fruits and vegetables, MPR 306. In all these cases, the standards were formulated by the Department of Agriculture. Controversy was aroused only by the canned fruits and vegetables program. For an example of a maximum price regulation which took into account both brand name and quality standards accompanied by grade labeling, see MPR 200 (Rubber Heels and Soles in the Shoe Repair Trade), Appendix C, infra.

T* For cxample, MPR 95 (Women's Nylon Hosicry), MPR 339 (Women's Rayon Hosiery), and MPR 274 (Women's Silk Hosiery), in all of which a label was required stating the denier and gauge , of the stocking, and RPS 89 (Bed Linens), which required labeling as to type and size.

is 89 Cong. Rec. 3246 (I943). 
history proves is the best guarantee yet devised for freedom of choice for the consumers, the opportunity to buy what they want when they want it . . if grade labeling goes through ... national advertising by manufacturers is going to fold up ..."76

This is not the only time that practices which in part serve to throttle free enterprise have been championed belligerently in the name of free enterprise. Nevertheless, if we agree, as I do, that brand names and brand-name advertising can serve a useful economic function, the argument that the suggested program will eliminate them deserves careful consideration. It is encouraging, therefore, to learn that Congressman Lanham, the father of the Trade-Mark Act of 1946 , was not concerned about this argument. During the height of the attack upon OPA's grade labeling activities Congressman Lanham said:

I see no particular objection to grades being posted on a label under a trade-mark, because that would further inform the public, but to do away with ... trade-marks would to me seem unconscionable. ${ }^{77}$

Of course, OPA never proposed to "do away with trade-marks." Whatever foundation there was for the charge that this would be the inevitable result of OPA's activities was based on the fact that in many cases OPA did not provide a means of pricing articles which did not conform to the quality standards specified, and that for a long time OPA refused to provide branded goods with a price premium simply because they were branded. ${ }^{78}$ Whether OPA was justified in the position it took is not now important, because we are considering the desirability of quality standards, informative labeling, and grade labeling in the absence of price control. But the question still remains, even in the absence of price control: Why should a consumer who, for example, has the choice of buying two rubber tires marked "Grade A," certifying that each complies with the specifications for a Grade A tire promulgated by the Government, pay more for one than the other simply because it carries a nationally advertised brand name? So put, why indeed should he? Even so, there is no reason to believe that persuasive advertising would disappear entirely. Advertisers might still seek to persuade consumers to buy the brand-name article. Whether they were successful would depend upon the extent to which the consumer acquired confidence in and knowledge about the grading and labeling system. Intensification of persuasive advertising to overcome the effect of government-promulgated quality standards and informative and grade labeling would clearly not be in the public interest. It is more probable, however, that the effectiveness of persuasive advertising would be weakened as consumers gained experience with the new guides to buying

\footnotetext{
70 Testimony of George S. McMillan, Secretary, Association of National Advertisers, Inc., Boren Committee Hearings, supra note 42 , at 202, 207.

${ }^{77} 89$ Conc. Rec. 3245 (I943).

${ }^{78} \mathrm{See}$, for example, MPR 95 (Women's Nylon Hosiery); MPR 339 (Women's Riayon Hosiery); and MPR' 306 (Certain Packed Food Products), Appendix C, infra. It was not until November 15, 1945, that a premium price for branded nylon hose was established, MPR 602, 10 F. R. I425I (I945); a premium for branded rayon hose was not established until January 4, 1944, Second RMPR 339, 9 F. R. 207 (1944). At no time was a price premium established for branded canned goods.
} 
made available to them. However, if it is true that brand-name articles generally are better quality articles, as is claimed, they will carry the highest grade notations. This should provide the basis for a very effective campaign of informative advertising. In addition, because the quality standards formulated will in most cases be minimum standards, there will always be the opportunity to inform the consumer, by advertising, why the brand-name article is of better than minimum quality and deserving of a premium price, if one is sought. There is little danger, therefore, that the suggested program will eliminate either brand names or brand-name advertising. But we may expect some shift of emphasis from persuasive to informative advertising, which would be in the public interest. ${ }^{79}$

C. The Program Will Jeopardize the Position of the Independent Retailer and Small Manufacturer

This argument assumes that if the suggested program makes any headway, it will weaken the efficacy of the brand name as a guide to consumer buying. It is then argued that, as a consequence, the position of the independent retailer will be jeopardized because he relies heavily on brand-name merchandise to maintain his clientele in the face of price competition from the chains. ${ }^{80}$ Implicit in this argument is the assumption that people patronize the independent retailer, and not the chain, only because they do not know that the chain's prices are lower than the independent's and that brand names help to keep the buyer in ignorance. It is doubtful, however, whether this assumption has much validity. People patronize the independents for a variety of reasons, among them because the independents are better located or furnish services which the chains do not, or simply because the "little fellow" is preferred on principle. Ignorance of the consumer, even if it is a factor, is hardly a basis upon which the continued existence of independent retailers should be made to depend.

A similar argument is advanced that brand names also give the small manufacturer some protection against price competition which would be taken away from him by the proposed program. This argument has even less to commend it. The basic objective of our antitrust laws is to make it possible for all enterprises to engage in more, not less, price competition. If the day has come when small business needs an umbrella of protection against bona fide price competition in order to survive, then its further existence has lost much of its justification. The truth of the matter is that persuasive advertising of brand names is, above all, the means by which large units seek to protect themselves against price competition. The suggested program will make it possible for the small manufacturer who is able to produce quality products to compete pricewise with larger units in the field, because it will free him from the necessity of making heavy outlays for persuasive advertising which he can-

${ }^{70}$ Brown, Advertising and the Public Interest: Legal Protection of Trade Symbols, 57 YALE L. J, 1165 (1948).

${ }^{80}$ Boren Committre Report, supra note 12 , at 15,38 . 
not afford and yet which are necessary under present conditions if he is to capture any part of the market. ${ }^{81}$

\section{The Program Will Lessen the Variety of Commodities}

It is difficult to evaluate this argument. Certainly simplification, as has been pointed out, is not an objective of the suggested program. Manufacturers will continue to produce goods of superior or inferior quality as measured by the minimum standards promulgated officially if they can find a market for them; and there is no reason why they should not find a market if their price differentials are appropriate. Nevertheless, some lessening of variety may be a result of the program. To balance this in the scales of judgment is the probability that the goods actually produced will be of better quality.

\section{E. The Program Will Add to the Host of Bureaucrats Interfering With American Business}

This argument against the program was made very strongly in the Thirties, when the idea of government intervention in business life was anathema to more people than it is today. To those who may still think that any further government intervention is undesirable in principle, it may be pointed out that government intervention to make our competitive system work is not a novelty. The only question is whether the means used will destroy the end. We do not think they do in connection with the antitrust laws. The proposed program will effectively supplement the antitrust laws in the pursuit of a workable competitive system.

\section{$\mathrm{V}$}

\section{Conclusion}

Many students of our economic system have deplored the emphasis it places upon the interest of the producer to the neglect of the consumer, whose welfare is its only justification. This is reflected in the curricula of our universities and explains the absence of representation of the consumer interest in government. ${ }^{82}$ However, we may be about to witness a change. The President in his recent State of the Union Message recommended that "the governmental agency which now administers the programs of health, education and social security should be given full departmental status." 83 Possibly in time this new department, if it is established, will assume the special responsibility of furthering the interest of the people as consumers in all its manifold aspects.

\footnotetext{
${ }^{81}$ See, for example, testimony of Jerome W. Ephraim, a manufacturer of toothpaste, in Hearings before the Temporary National Economic Committee, 76th Cong., Ist Sess. 3396-3412 (1939).

82 "Consumer interest . . . is concerned with income spending . . .

"The consumer interest, then, is a special interest. Only when it is so understood will fruitful efforts be made to do something about it. To lump it indiscriminately with the public interest serves merely to dismiss it from further consideration. To define it vaguely as everyone's business is to make it precisely no one's business. Its stunted growth as an object of public concẹrn until now is most readily explained as being due to just such protective thinking concerning it." Final Report of the Executive SecreTARY ro THE TNEC, 77th Cong., Ist Sess. 320,321 (I941).

${ }^{83}$ N. Y. Times, Jan. 6 , I949, p. 4 , col. 5 .
} 


\section{APPENDIX A}

OPA Quality Controls in Maximum Price Regulattons Which Did Not Use Uniform Dollar-and-Cents Prices

OPA attempted to combat hidden inflation resulting from quality deterioration even when pricing techniques other than uniform dollar-and-cents pricing were used. Thus, for example, the General Maximum Price Regulation, issued April 28, 1942, 7 F.R. 3153, fixed as the seller's maximum price for any commodity or service the highest price charged by him during March, 1942 , for the same or similar commodity or service. It was then provided that one commodity shall be deemed "similar" to another if, inter alia, it "affords the purchaser fairly equivalent serviceability." The obvious difficulties with this standard constituted one of the main weaknesses of this type of regulation.

In subsequent freeze-type regulations, an attempt was made to define "equivalent serviceability" in terms of stated standards and specifications. Thus, for example, MPR 22I (Manufacturers' Prices for Fall and Winter Knitted Underwear, issued and effective September 15, 1942, 7 F.R. 7318), provided that "A garment is the same as another garment with which it is compared if both garments have all of the following common characteristics: (i) They are of the same specific classification and size as provided by the United States Department of Commerce, Commercial Standard CS 33-32; (ii) They have the same average finished weight for comparable size, within a tolerance of $3 \%$; (iii) They are knitted from the same kinds of yarn (for example, carded, combed, blended or processed staple fiber yarns), and with the same percentage of fibers (for example, cotton, wool or other fibers and mixtures thereof); (iv) They have a substantially equal number of courses and needles per inch; (v) They have construction and trimmings of substantially equal quality and serviceability; (vi) They are constructed and finished with substantially equal standards of workmanship."

These problems of similarity were particularly acute in the consumer durable goods field at the beginning of the war effort, when new materials had to be substituted for the metals devoted to war production, and at the end, when the problems of reconversion loomed so large. Regulations covering consumer durable goods specified that quality testing, usually by the Bureau of Standards, would be used as the basis for determining similarity or "comparable serviceability." See, for example, MPR 188, PIKE AND FIscher OPA Service Ig:20I.

In one and only one instance-soap-the OPA issued a regulation absolutely prohibiting new styles, sizes, qualities, and shapes of a commodity. Commodity Practices Regulation No. I (Bar or Package Soaps or Cleansers, issued July 7, 1942, 7 F.R. 5564, 8 F.R. 4930, I4348). See Statement of Considerations for Commodity Practices Regulation No. I, PiKe ANd Fischer OPA Service 62:1rI. "The regulation prohibited any change in weight or quality of bar or packaged soaps or cleansers, except as permitted. The nature of the soap industry was such that any bar or packaged soap or cleanser could be marketed with changed and cheaper ingredients and could not be distinguished by the consumer from bars or packages previously sold. This made evasions of the GMPR almost impossible to detect. The incentive to deteriorate content was heightened by the fact that if all or part of the cost saving were expended in deals making the purchase more attractive to the consumer, new markets might be obtained by any manufacturer at the expense of others who kept their quality unchanged. Moreover, even if OPA should undertake to set new prices for each new item, it would be unlikely to set them equitably, since a padding of even one cent in the cost or price might be decisive, in view of the low price of the commodity, and the fractional differences in cost. In view of these circumstances, OPA felt justified in prohibiting any changes in weight or 
quality." Harold Leventhar, Problems in Price Control: Legal Phases 95, 96 (Historical Reports on War Administration: Office of Price Administration, General Publication No. II, I947).

Commodity Practices Regulation No. I was revoked December 28, I944 (effective January 2, 1945), 9 F.R. I5106. Its principal features were incorporated in MPR 39I (Household Soaps and Cleansers Sold by Manufacturers and Certain Wholesalers, issued May I4, 1943, effective May 24, r943, 8 F.R. 6268, by Amendment 4 to that regulation, issued December 28, I944, effective January 2, I945, 9 F. R. I5I48), except that under MPR 39I, permission to introduce new or changed products was granted much more liberally. See Statement of Considerations Accompanying Amendment 4, OPA Chemicals and Rubber Desk Book, 9533.

\section{APPENDIX B \\ Office of Price Administration \\ Washington, D. C.}

Administratrve Order No. 49

The Standards Division

September 3, 1942

Section 4. Functions of the Standards Division. There is hereby established the Standards Division which shall perform the basic functions of identifying products and services to which price control is applied and specifically:

A. x. Develop technical commodity definitions, standards, specifications and classifications and other quality identifying techniques for the use of the price, rationing and rent divisions in their operations.

2. Develop methods of determining "fairly equivalent serviceability" for use in pricing "similar" commodities.

B. Develop programs for informative labeling of commodities and assist in the preparation of labeling requirements for incorporation in price, rationing, rent and commodities practices regulations.

C. Initiate and develop simplification practices and requirements necessary to effective price and rationing controls and the adjustment of civilian production to war conditions by performing the following functions:

r. With the assistance of the price and rationing branches concerned and of public and private technical agencies determine the necessity and feasibility of simplified practices requirements for commodities in situations where there are:

a. Shortages of materials, labor, plant or distribution capacity; or

b. Inadequate operating margins resulting from ceiling prices.

c. Such a multiplicity of varieties that effective price regulation is not feasible. ${ }^{1}$

2. Present such requirements to representatives of business units and public agencies concerned in order to secure appraisal and acceptance of the project and to appropriate officers within the War Production Board in order to secure their promulgation.

3. Develop for the use of the price branches quality definitions'and labels for products covered by such simplification requirements.

1 This provision was added by OPA Administrative Order No. 67, issued December 14, 1942, which established a Professional Services Department (superseding the General Services Department) of four divisions, one of which was the Standards Division. National Archives. (Author's footnote.) 
D. Collaborate with the Office of Industry Branches, Conservation Divisions, and the Office of Civilian Supply of the War Production Board and with industrial organizations, and public and private research groups in developing programs designed to make the most effective use of supplies of scarce raw materials, labor, manufacturing, plant and distribution capacity available for the production of civilian goods by:

r. Increasing production efficiency through improved production techniques.

2: Improving design of commodities.

3. Substitution of materials.

E. I. Have exclusive responsibility within the Office of Price Administration for the function of testing. Officers of other OPA divisions and branches shall secure the use of testing facilities only through the Standards Division.

2. Secure such testing of commodities as may be necessary in connection with the development of commodity definitions and labels and the detection of quality deterioration.

3. Act in a consulting capacity to the enforcement staff:

a. To establish sampling and test methods to identify commodities and services involved in the administration and enforcement of price, rent and rationing orders.

b. To secure such testing and technical facilities as may be required in connection with such determinations.

c. To prepare instructions to field staffs on technical problems involved in such operations.

F. Act in a consulting capacity to the price, rent, and rationing staffs in the technical analysis, comparison and evaluation of services which involve commodities.

G. Through appropriate operating organization units in the National Office, explain to field staffs commodity definitions and quality provisions of price, rent and rationing regulations.

H. Supply to the public through the Consumer Division and the Information Office and to other OPA organization units for use in connection with their respective functions information on commodity definitions, specifications, informative labeling, simplification and substitution.

I. Serve as the primary channel of contact and liaison between the various offices and organization units of OPA and other public and private technical agencies, including those agencies mentioned in this Order, in connection with all problems for which the Standards Division is assigned primary responsibility.

\section{APPENDIX C}

I

Regulations in Which the Price Administrator Found that the Standards and Specifications Used in the Regulation Were in General Use in the Trade or Industry Affected Prior to Their Use in the Regulation

Revised Price Schedule No. 50 (Green Coffee) 7 F.R. 1305, 2132, 2945, 5462, 6387, 6685, 8948 , x047, 8 F.R. 5477

RPS 5I (Cocoa Beans and Cocoa Products) 8 F.R. 2335, $5^{6} 33$

RPS 52 (Pepper) 7 F.R. 1308, 2132, 8948

RPS I6 (Raw Cane Sugar) 7 F.R. I239, 2133, 2132, 8948, 8 F.R. 6842

RPS 60 (Direct Consumption Sugars) 7 F.R. 1320, 2132, 2510, 5664, 6787, 8928, 8948, 8949, 8 F.R. 5809, 6044, 6424, 9288 , ro079 
RPS 9x (Tea) 8 F.R. $x 98$ I, 3 I 78

Maximum Price Regulation No. 227 (Dried Fruits) 7 F.R. 7531, 8948, 8 F.R. I97I, 3197, 6445

MPR 23r (Raw Spices and Spice Seeds) 7 F.R. 7844, 8948, $913^{\circ}$

MPR 233 (Dried and Canned Apples and Apple Products) 8 F.R. 4632, 4628

MPR 242 (Dried Prunes and Raisins) 7 F.R. 8354, roro8

Revised Maximum Price Regulation No. 270 (Dry Edible Beans and Certain Other Dry

Food Commodities) 8 F.R. I061, 2335, 3106, 3370, 4732, 5810, 9335, ro986

RMPR 27I (Potatoes and Onions) 8 F.R. 7017, 7494, 8075, 9160, ro73

MPR 291 (Certain Syrups and Molasses) 7 F.R. I1002, 8 F.R. 2713, 2714, 3621, 66r8

MPR 292 (Citrus Fruits) 8 F.R. 135, 543, 2869, 3367, 6134, 10432

MPR 308 (Connecticut Shade Grown (Type No. 6I) Tobacco) 8 F.R. Ir36, 7260

MPR 312 (Maple Syrup and Maple Sugar) 8 F.R. r266, 2032, 484I, 6052, 6445, 8844

RMPR 335 (Peanuts and Peanut Butter) 8 F.R. 6834, 10264, I0987

MPR 362 (Gelatin) 8 F.R. 4519

MPR 363 (Flue Cured Tobacco Plants) 8 F.R. 4260

MPR 428 (Cider Vinegar) 8 F.R. $1035^{8}$

MPR $44^{\circ}$ (Georgia and Florida Shade Grown Tobacco of the 1943 Crop) 8 F.R. 10264

MPR 44I (Flue Cured Tobacco) 8 F.R. ro443

RPS 73 (Fish Meal) 7 F.R. 2475, 2637, 859r, 8 F.R. 877, 9286

RMPR 74 (Animal Product Feeding Stuffs) 8 F.R. 9626, I0905

RMPR I35 (Mixed Fertilizer, Superphosphate and Potash) 8 F.R. I459, 362x, 8540, 10572

RMPR $15^{\circ}$ (Finished Rice and Rice Milling By-Products) 8 F.R. 4788 , ro758

MPR 205 (Fertilizer Raw Materials) 7 F.R. 6482, 8948, 3255

MPR 240 (Phosphate Rock) 7 F.R. 8283, 8948, 8 F.R. 3056, 3370

MPR 315 (Arsenical Insecticides) 8 F.R. I586, 2350, 4I87

RMPR $37^{\circ}$ (Linseed Oil Meal, Cake, Pea Size Meal and Pellets) 8 F.R. ro733

MPR 401 (Certain Corn Products for Animal Consumption) 8 F.R. 7567, 9774

MPR 404 (Potash) 8 F.R. 8067

MPR 442 (Peanut Oil Meal, Cake, Sized Cake, Pellets and Peanut Hulls) 8 F.R. 10736

MPR 443 (Soybean Oil Meal, Cake, Pea Sized Meal and Pellets) 8 F.R. 10759

MPR 444 (Cottonseed Oil Meal, Cake, Sized Cake and Pellets; Cottonseed Hulls and

Hull Bran and Whole Pressed Cottonseed) 8 F.R. I0903

RPS 88 (Fuel Oil, Gasoline and Liquefied Petroleum Gas) 8 F.R. 3718

MPR I37 (Petroleum Products at Retail) 8 F.R. 4092, 45II, 4335, 5583, 6r20

MPR 323 (Asphalt and Asphalt Products) 8 F.R. 2xo1, 384I, 5383, 6109

RPS 42 (Paraffin Wax) 7 F.R. 2000, 2r32, 3430, 4853, 8202, 8948, 8783, 8 F.R. 5483

RMPR 213 (New Coil and Flat Bedsprings) 8 F.R. $150,485^{\circ}$

MPR 380 (Used Metal Coil and Flat Bedsprings) 8 F.R. 5929, 71r4

RMPR I39 (Used Household Mechanical Refrigerators) 8 F.R. 3706, 5484, 9779, x0079 MPR 294 (Used Household* Vacuum Cleaners and Attachments) 8 F.R. I39, 3528, 8979

RPS 45 (Asphait or Tarred Roofing Products) 8 F.R. 1369, 3853, 5590

RPS 96 (Domestic Fuel Oil Storage Tanks) 7 F.R. 1387, 2132, 3774, 5360, 8383, 8948

MPR 175 (Rough Rolled, Figured, Wire and Heat Absorbing Rolled Glass) 7 F.R. 5188, 53 Io, 8948

MPR 206 (Vitrified Clay Sewer Pipe and Allied Products) 7 F.R. 6424, 8948, 8944, 8

F.R. 1313

MPR 224 (Cement) 7 F.R. 7396, 8650, 8944, 9495, 8 F.R. 8275 
MPR 272 (Cast Iron Boilers and Cast Iron Radiators) 7 F.R. 9486, 9972, 10618, 8 F.R. 6356

MPR 382 (Wide Mouth Glass Containers) 8 F.R. 6275, 8839, 106r 8

RMPR I3 (Douglas Fir Plywood) 7 F.R. roor7, 8 F.R. I588, 2993, 4779, 53 r9

RMPR ig (Southern Pine Lumber) 8 F.R. 5536, 6544, 66r9, 8979, 10732

RMPR 26 (Douglas Fir Lumber) 8 F.R. 7570, 95r9

RPS 44 (Douglas Fir Doors) 7 F.R. 1288, 7963, 8948

MPR 94 (Western Pine Lumber) 7 F.R. 10848, 8 F.R. 859, r138, 4118, 7352, 8009, $875^{6}$

RMPR 97 (Southern Hardwood Lumber) 8 F.R. 142, 3530, 5177, 5479, 8860, 10762

MPR I46 (Appalachian Hardwood Lumber) 7 F.R. 3776, 4179, 4852, 5520, 6053, 6998, 7600,8 I98, 8350, 8384, 8984, 8 F.R. 3056, 5479, 9998

MPR 155 (Central Hardwood Lumber) 7 F.R. 4ro9, 7202, 7780, 8385, 8948, 8 F.R. 3056, $384^{8}, 94 \mathrm{I} 7$

MPR 164 (Red Cedar Shingles) 7 F.R. 454r, 8384, 8948, 8 F.R. 2876, 2992, $45^{14}$

MPR r76 (Rotary Cut Southern Hardwood Box Lumber) 7 F.R. 5r8o, 7243, 7454, 8949, 8 F.R. 2993, 4720, 7490

RMPR I86 (Western Wooden Agricultural Containers) 8 F.R. r59x, 3529, 3842, 4479, 6 I77, 7505, 8505, 9778

RMPR 216 (Railroad Ties) 7 F.R. x0782, 8 F.R. 434, 7268

RMPR $2 \times 8$ (Eastern Wooden Mine Materials and Industrial Blocking) 7 F.R. 7824,8 F.R. $493,1028,2887,2993,6362$

RMPR 219 (Northeastern Softwood Lumber) 8 F.R. 4948, 6620, 9779

RMPR 222 (Northern Softwood Lumber) 8 F.R. 8362, 9382, 9779, ro937

MPR 223 (Northern Hardwood Lumber) 7 F.R. 7445, 8945, 8 F.R. 121, 2783, 5480, 562 9 , 8945, ro939

MPR 253 (Redwood Lumber and Millwork) 7 F.R. 9230, ro848, 8 F.R. II39, 4136, 4720, $7 \mathrm{rg7}$

RMPR 284 (Western Primary Forest Products) 8 F.R. 6544, 10560

MPR 290 (Sitka Spruce Lumber) 8 F.R. 19, 2270, 6959

MPR 293 (Stock Millwork) 8 F.R. 167, 8947

MPR 368 (Northeastern Hardwood Lumber) 8 F.R. 4968, 854r, 10660

MPR 38I (Stock Screen Goods) 8 F.R. 6159, 7x98

MPR 402 (Western Red Cedar Lumber) 8 F.R. 7662

MPR $4^{12}$ (Tidewater Red Cypress) 8 F.R. $87 \times 2$

MPR 424 (Tight Cooperage Stock and Sawed Tight Cooperage) 8 F.R. 9516

MPR 432 (Maple, Birch, and Beech Flooring) 8 F.R. roo79

RPS 6 (Iron and Steel Products) 6 F.R. 2004, 306r, 7 F.R. 785, 930, 1215, 2132, 2153, 2299, 2997, 3II5, 394I, 4780, 7240, 8948, 8 F.R. 6042, 6440, 7257

RPS Io (Pig Iron) 8 F.R. 1236, 2482, 4627

RPS $_{41}$ (Steel Castings) 8 F.R. 2275, 3844, 8675, $975^{\circ}$

RPS 43 (Used Steel Drums, Pails, and Containers and Reconditioning of Used Steel Drums) 6 F.R. 6596r, 7 F.R. 206, 6r8, 656, x287, 2132, 4297, 8948, 10527, 8 F.R. 3188, 4968,5809

MPR 46 (Relaying Rail, Relaying Girder Rail and Used Track Accessories) 6 F.R. 6185, 7 F.R. 656, 809, 904, I295, 2132, 2508, 3446, 8948, 10528, 8 F.R. 5529

RPS 49 (Resale of Iron or Steel Products) 8 F.R. 4608, 4542, 7257, 7595, 7769, 7909, 9750

MPR 113 (Iron Ore Produced in Minnesota, Wisconsin or Michigan) 7 F.R. 2680, 2760, 4854,8948 , I0108, 8 F.R. 4644

MPR I47 (Bolts, Nuts, Screws and Rivets) 7 F.R. 3808, 3905, 8948, 8 F.R. $836 \mathrm{~T}$ 
MPR I59 (Fabricated Concrete Reinforcing Bars) 7 F.R. 4339, 4428, 5710, 8948, 8 F.R. 970, 1202

MPR 2I4 (High Alloy Castings) 7 F.R. 700r, 8948, r0302

MPR 3 I0 (Reusable Structural Steel Shapes and Plates, and Shafting) 8 F.R. I225, 5808

RPS 32 (Paperboard Sold East of the Rocky Mountains) 7 F.R. 1264, 2000, 2132, 2740, 3182, 8949

MPR 129 (Certain Converted Paper Products) 7 F.R. 3178, 3242, 3482, 3554, 4I76, 4668, 5172, 5780, 5712, 5943, 7974, 8939, 8948, 9r3r, 9724, ror52, ro8r2

RMPR 257 (Pulpwood Produced in States of Minnesota, Wisconsin and Michigan) 8 F.R. I1037, 9 F.R. 5909, 12263.

MPR 307 (Waxed Paper) 8 F.R. 1389,2335

MPR 349 (Distributors' Maximum Prices for Certain Coarse Paper Products) 8 F.R. $3617,6110,7266$

MPR 359 (Certain Converted Paper Products) 8 F.R. 4635, 4727, 6736

MPR 365 (Wood Matches and Resale Book Matches) 8 F.R. 4721

MPR 369 (Dry Roofing and Flooring Felts) 8 F.R. $5^{\text {I } 74}$

RMPR 387 (Pulpwood Produced in the States of South Carolina, Georgia, Florida, Tennessee, Mississippi, Alabama, and Louisiana East of the Mississippi River)

MPR 95 (Women's Nylon Hosiery) 7 F.R. 852I, 8948, 9492, 8 F.R. 8502

MPR 274 (Women's Silk Hosiery) 7 F.R. 995I, 10378, I079I, 8 F.R. 8512, 8860

MPR 3 (Zinc Scrap Materials and Secondary Slab Zinc) 8 F.R. 3r7r

MPR 8 (Pure Nickel Scrap etc.) 7 F.R. r224, 2132, 3123, 3270, 3519, 4493, 5514, 8948

RPS 12 (Brass Mill Scrap) 7 F.R. 1234, 2132, 3520, 5515, 8650, 8948, 9392, 8 F.R. 3189, 3852,4928

RPS 15 (Copper) 7 F.R. 283, 1237, 2132, 2944, 58rr, 8948

RPS 69 (Primary Lead) 7 F.R. 284, 726, 936, 1339, 2132, 2278, 2997, 8948, 8 F.R. 612, $394^{8}$

RPS 8I (Primary Slab Zinc) 7 F.R. 60I, 70r, I356, 2000, 2r32, 2997, 8948

RMPR 126 (Fluorspar) 7 F.R. 3189, 8948, 9490, 8 F.R. 437, 5170, 5987, 9162

RMPR ${ }_{3} 8$ (Ferromanganese and Manganese Alloys and Metal) 7 F.R. 3212, 3448, 5646, $8948,6168,9227$, ro762

MPR I66 (Zinc Oxides) 7 F.R. 4585 , 470r, 5310, $894^{8}$

MPR 198 (Silver) 7 F.R. 6083, 6936, 8948

MPR 202 (Brass and Bronze Alloy Ingot and Shot) 7 F.R. 642I, 8 F.R. r449, 9 F.R. $345^{8}$

MPR 248 (Manganese Ores) 7 F.R. 8694, I0017, 8 F.R. 2109

MPR $25^{8}$ (Chrome Ores) 7 F.R. 9002, 8 F.R. 337r, 7r98, 9787

MPR 309 (Platinum Group Metals and Their Products) 8 F.R. I233

MPR 314 (Magnesium and Magnesium Alloy Ingot) 8 F.R. 1367, 2040, 2154, 7106, 10667

MPR 405 (Ferrosilicon and Silicon Metal) 8 F.R. 818x, 10759

MPR 407 (Ferrochromium and Chromium Metal) 8 F.R. 8075, 8550, 9024

RPS 2r (Formaldehyde) 7 F.R. I249, 2000, 2r32, 820r, 8948, 9894

RPS 31 (Acetic Acid) 7 F.R. I263, 2000, 2132, 820r, 8948, 9894

MPR 36 (Acetone) 7 F.R. 1276, 2000, 2132, 6655, 7001, 7910, 894r, 8948

MPR 38 (Glycerine) 7 F.R. I277, 2000, 2132, 2997, 5178, 8202, 8948, 8 F.R. 155, 6r77

RPS 68 (Hide Glue Stock) 7 F.R. $1338,2000,2132,224 x, 2948,3125,5362,6474$, 8948, 8 F.R. r68r

RPS 76 (Hide Glue) 7 F.R. I35x, 2132, 224I, 28ז8, 4381, 8948, 8 F.R. ${ }_{3} 65$

RPS 78 (Oxalic Acid) 7 F.R. 1353, 2132, 2512, 8202, 8948

MPR 79 (Carbon Tetrachloride and Certain Blends Thereof) 8 F.R. 10728 
RPS 8o (Lithopone) 7 F.R. 1355, $1643,2132,2759,8203,8948,9895$

RPS 98 (Titanium Pigments) 7 F.R. I392, 2108, 2132, 8203, 8948, 9845

RMPR I7I (Film Scrap) 8 F.R. 8547

MPR I79 (Pine Oil) 7 F.R. 5482, 8216, 8948

RMPR I92 (Imported Tar Acids) 7 F.R. 5999, 8217, 8948, I0705, 8 F.R. 3372

MPR 203 (Vitamin A Natural Oils and Concentrates) 7 F.R. 6476,8948

MPR 245 (Shellac) 7 F.R. 8556, 8948

MPR 264 (Industrial Waxes) 7 F.R. 9x93, 8 F.R. 2507

MPR 278 (Totaquina and Totaquina Products) 7 F.R. ro153, 8 F.R. 3002

MPR 282 (Certain Private Formula Pharmaceutical, Proprietary Drug, and Cosmetic

Products) 7 F.R. ro343

MPR 297 (Natural Resins) 8 F.R. 263

MPR 345 (Thermoplastic Scrap) 8 F.R. 3320, 3795

MPR 352 (Chestnut Extract) 8 F.R. 3793

MPR 354 (Copper Sulphate) 8 F.R. 3943, 5809, 6r 76,7765

MPR 406 (Synthetic Resins and Plastic Materials) 8 F.R. $837^{2}$

MPR 43r (Charcoal) 8 F.R. 9628

RPS 87 (Scrap Rubber) 7 F.R. 478I, 5177, 6002, 8700, 8948, 8 F.R. 4628, 5986

MPR 301 (Retail and Wholesale Prices for Rubber Drug Sundries) 8 F.R. 9212

RPS 9 (Hides, Kips and Calfskins) 7 F.R. x227, 2000, 2132, 5706, 8948, 8 F.R. 2997

RPS 18 (Burlap) 7 F.R. I24r, I600, 2000, 2r32, 5138, 7435, 8948

RPS 24 (Washed Cartle Tail Hair and Winter Hog Hair) 7 F.R. 1254, 2000, 2132, 8948, 9430

RMPR 55 (Second-Hand Bags) 7 F.R. I0104, 10554, 10585

RPS 59 (Kapok) 7 F.R. I319, 2000, 2132, 8948

MPR I06 (Domestic Shorn Wool) 7 F.R. I648, 2245, 2397, 4338, $894^{8}$

MPR I45 (Pickled Sheepskins) 7 F.R. 3746, 3889, 5771, 5835, 8948, Ir074, 8 F.R. 5724

MPR 357 (India-Tanned Goatskins) 8 F.R. 4474

MPR 360 (Binder Twine) 8 F.R. 4484,6 I 82

MPR 420 (Hardwood Heel Blocks, Finished Hardwood and Synthetic Hardwood Heels and Wood Shanks) 8 F.R. 933I

RMPR 34 I (Used Commercial Motor Vehicles) 8 F.R. 5887

MPR 375 (Used Industrial Sewing Machines and Rental Rates for New and Used Industrial Sewing Machines) 8 F.R. 7 II $_{4}$

MPR II (Fine Cotton Goods) 8 F.R. 36r, 2206, 4629, 4725, 5477, 8065, 76r5, 8937

RPS 23 (Rayon Grey Goods) 7 F.R. 2899, 2966, 2945, 3242, 348r, 677r, 8948

MPR go (Rayon Waste) 8 F.R. 2036

MPR I67 (Rayon Yarn and Staple Fiber) 7 F.R. 4662, 6895, 7493, 8948, 10449, 8 F.R. $\mathrm{I} 642$

MPR I68 (Converted Rayon Yarn and Converting Charges) 7 F.R. 4663, 8193, 8948, 8 F.R. 373,6673

MPR 325 (Rayon Tops and Rayon Noils) 7 F.R. 896r, 8 F.R. 2037, 6957, 933r

MPR $35^{8}$ (Insulation Cambric and Separator Cloth) 8 F.R. 448r.

II

Regulations in Which the Price Administrator Found that the Standards and Specifications Used in the Regulation Had Been Previously Promulgated and Therr Use Lawfuldy Required by Another Government Agency

MPR 33I (Soybeans) 8 F.R. 2343, 2781, 3837

MPR 397 (Flaxseed) 8 F.R. 6840, 7392, 10757 
RMPR 346 (Corn) 8 F.R. 4924, 7354, 8186, 9300

RPS 100 (Cast Iron Soil Pipe and Fittings) 7 F.R. 5132, 5276, 8383, 8948, 8 F.R. $6{ }_{17} 6$

RPS 85 (New Passenger Automobiles) 7 F.R. 1364, 1675, 2134, 2132, 6058, 6897, 7100 , 7436, 7942, 8948, 9899, 8 F.R. I450, 2040, 3213 .

III

Regulations in Which the Price Administrator Found that the Standards and Specifications Used in the Regulation Were in General Use in the Trade or Industry Affected Prior to Their Use in the Regulation or had .

Been Previously Promulgated and Their Use Lawfulity Required by Another Government Agency

MPR 280 (Specific Food Products) 8 F.R. 5165, 7566, 6357, 7196, 7599, 7670, 8065, 8180, 952I, 9386, 9883, 10513

MPR 289 (Dairy Products) 7 F.R. I0996, 8 F.R. 490, 1458, r885, 1972, 3252, 3327, 4335, $4513,4337,4338,4918,6440,7566,7593,8276,875 \mathrm{I}, 9380,9229$, 10667

MPR 329 (Milk) 8 F.R. 2038, 2874, 3252, 362x, 4726, 5933, 5907, 6737, 8063, 9884, ro731

Supplementary Regulation No. 14 A (Milk and Milk Products) 8 F.R. 9885, 10514

MPR 318 (Feathers and Down) 8 F.R. I682, 2029, 6476

RMPR rog (Aircraft Spruce Lumber) 7 F.R. roroo, 8 F.R. 270, 2872, 4325, 47I7, 6833, $86 \times 4$

MPR 217 (Walnut Gunstock Blanks) 7 F.R. 7244

MPR 28r (Navy Oak Ship Stock) 7 F.R. I0290, 8 F.R. 2107, 8678

MPR $35^{\circ}$ (Packers' Tin Cans and Condensed Milk Cans) 8 F.R. 378I

MPR $I_{14}$ (Woodpulp) 7 F.R. 2843, 3576, 5059, 5564, 8997, 8948, 8 F.R. 321, 2334, 8877, $1055^{8}$

MPR 400 (Merchants' Prices for Fine Papers and Certain Paperboards) 8 F.R. 7556

MPR 2 (Aluminum Scrap and Secondary Aluminum Ingot) 8 F.R. 8495, 8948, $933^{\circ}$

MPR I3I (Camelback and Tire and Tube Repair Materials) 8 F.R. 10566

MPR 300 (Rubber Drug Sundries) 8 F.R. 867, 1369, 1388, 1585

RPS 58 (Wool and Wool Tops and Yarns) 8 F.R. 5988

MPR I23 (Raw and Processed Wool Waste Materials) 7 F.R. 3088, 3330, 3829, 6477, 8948, 9325, 10708, 8 F.R. 9530

MPR I4I (Raw Shearlings and Tanned Shearlings for the Armed Forces) 7 F.R. 3520, 8949, 9812

RPS 35 (Carded Grey and Colored Yarn Cotton Goods) 8 F.R. 1963, 5306

MPR I 18 (Cotton Products) 7 F.R. 3038, 3211, 3522, 3578, 3824, 3905, 4405, 5224, 5405, $.5567,5836,6005,6484,7451,8217,894 x, 9002,8948,9969,8$ F.R. 274, 2338, 4r 37,5306 , 7267

MPR I27 (Finished Piece Goods) 8 F.R. 3057, 485r, 6r8r, 9023.

IV

Rigulations in Which the Price Admintstrator Found that the Standards and Specifications Used in the Regulation Were in General Use in the Trade or

Industry Affected Prior to Their Use in the Regulation and had Been

Previously Promulgated and Their Use Lawfully Required by ANother Government Agency

MPR 3 I7 (Locks and Lock Sets) 8 F.R. I800, 1983, 6357

MPR 413 (Hinges and Butt Hinges) 8 F.R. 8948, 9774

MPR 385 (Specified Military Uniforms) 8 F.R. 66 14, 8009, xo66r 
MPR 28 (Ethyl Alcohol) 8 F.R. 2339, 4256, 4852, 80r6

MPR 295 (West Coast Ethyl Alcohol) 7 F.R. xII15, 8 F.R. I29, 2599, $493^{\circ}$

Regulations in Which the Price Administrator Determined That in so far as the Regulation Used Standards and Specifications Which Were Not, Prior to Such

USE, in General Use in the Trade or Industry AfFected, or IN SO far as

Their Use Was Not Lawfully Required by Another Government

Agency, With Respect to Such Standardization, No Practicable

Alternative Existed for Securing Effective Price Control

MPR 275 (Extracted Honey) 7 F.R. 9955, 8 F.R. 542, I228, 2337, 3947, 8502, $92 \times 8$

MPR 296 (Flour from Wheat, Semolina and Farina) 8 F.R. 158, 612, 2598, 3703, 7567, $7599,8544,9159,10362$, 10758

MPR 298 (Rotenone and Pyrethrum) 8 F.R. $365,5589,6440$

RMPR 322 (Alfalfa Hay) 8 F.R. 8500

RMPR 269 (Poultry) 7 F.R. I0708, I0864, IIII8, 8 F.R. 567, 856, 878, 228g, 33I6, 3419, 3792

MPR 333 (Eggs and Egg Products) 8 F.R. 2488; 3002, 3070, 3735

MPR 372 (Used Domestic Washing Machines) 8 F.R. 5333

MPR 429 (Certain Used Consumer Durable Goods) 8 F.R. 9877

RMPR 162 (Used Typewriters) 8 F.R. 9779

MPR 416 (Basic Refractory Products) 8 F.R. 8940

MPR 313 (Prime Grade Hardwood Logs) 8 F.R. 1453, 2209, 2992, 5564, 6359, 10825

RMPR 230 (Reusable Iron and Steel Pipe and Used Structural Pipe) 7 F.R. 773x, 7914, 8935, 8 F.R. x62I, 3520

MPR 4 II (Reusable Steel Storage Tanks) 8 F.R. $885 \mathrm{I}$

RPS 4 (Iron and Steel Scrap) 8 F.R. 1952, 2431, 7264

RMPR I48 (Dressed Hogs and Wholesale Pork Cuts) 7 F.R. 8609, 9005, 8948, 8 F.R. $544,2922,3367,4785,7322,7671,7826,8376,8677,10571$, 10732

RMPR x69 (Beef and Veal Carcasses and Wholesale Cuts) 8 F.R. 4097, 4787, 4844, 5170, 5478, 5634, 6058, 6427, 7ro9, 6945, 7199, 7200, 80x 1, 8677, 8756, 9066, 9300, 9995

RMPR 239 (Lamb and Mutton Carcasses and Wholesale Cuts) 7 F.R. ro688, 8 F.R. $35^{89}, 4786,7679,8677,9066$

MPR 247 (Domestic Canned Crabmeat) 7 F.R. 8653, 8948, II811

MPR 252 (Vinegar Cured Herring) 7 F.R. 8875, x0476, 8 F.R. 3706

MPR 299 (Sales by Canners of Tuna, Bonito and Yellowtail) 8 F.R. 364, 6440, 7489.

MPR 303 (Frozen Canadian Smelts) 8 F.R. 6r9, 2ro7

MPR 3 II (Sales by Canners of Shrimp) 8 F.R. I269

MPR 336 (Retail Ceiling Prices for Pork Cuts and Certain Sausage Products) 8 F.R. $2855,4253,5317,5634,6212,7682,8944,9366$

MPR 389 (Ceiling Prices for Certain Sausage Items at Wholesale) 8 F.R. 5903, 6958, $6945,8 \mathrm{r} 85,8677$

MPR 355 (Retail Ceiling Prices for Beef, Veal, Lamb and Mutton Cuts and all Variety Meats and Edible By-products) 8 F.R. 4423, 4922, 6214, 6428, 7199, 7827, 8185, 8945, 9366

MPR 364 (Frozen Fish and Seafood) 8 F.R. 4640, 5566, 7592, III75, 12023

MPR 384 (Sales by Processors of Salt Codfish, Hake, Haddock, Cusk and Pollock) 8 F.R. 6II0, 7489

MPR 394 (Retail Ceiling Prices for Kosher Beef, Veal, Lamb and Mutton Cuts and all Variety Meats and Edible By-products) 8 F.R. $6_{3} 6_{4}$ 
MPR 398 (Variety Meats and Edible By-products at Wholesale) 8 F.R. 6945, 735I

MPR $3^{\circ}$ (Wastepaper) 8 F.R. 3845, 6I09, 7350, 7199, 7821

MPR 47 (Waste Rags, Waste Ropes and Waste Strings) 8 F.R. 270

RMPR 130 (Standard Newsprint Paper) 7 F.R. 925r, 10255, 8 F.R. 1586, 2670, 7766

MPR 266 (Certain Tissue Paper Products) 7 F.R. 9229, 10379, Iroo9, 8 F.R. I64, 606, 9380

MPR 344 (New Cotton, Linen and Underwear Cuttings) 8 F.R. 3r98, 6ro9

MPR r82 (Kraft Wrapping Papers and Certain Bag Paper and Certain Bags) 7 F.R. 5712, 6048, 7974, 8997, 8948, 9724

MPR̂R 208 (Staple Work Clothing) 7 F.R. 6649, 8940, 8948, 10015, 8 F.R. 4887

RPS ${ }_{77}$ (Tin) 7 F. R. 1240, 2132, 2395, 4539, 8948, 8 F.R. 4782

MPR 20 (Copper Scrap and Copper Alloy Scrap) 7 F.R. 7I3, 815, 905, II31, I245, I643, 2106, 2132, 2897, 3242, 3404, 3489, 5516, 6482, 6895, 8948, 8 F.R. I20, 3189, $755^{6}, 93^{88}$

MPR 70 (Lead Scrap Materials) 7 F.R. 4000, 1346, 2132, 4586, 8708, 9848

MPR 302 (Magnesium Scrap and Remelt Magnesium Ingot) 8 F.R. 609, 8842, ro433

MPR 379 (Tool Steel Scrap) 8 F.R. 5844

MPR 37 (Butyl Alcohol and Esters Thereof) 7 F.R. 6657, 700r, 79ro, 894I, 8948, 8 F.R. $6046,8874,9884,10672$

MPR I70 (Anti-Freeze) 7 F.R. 4763, 5717, 8948, 8 F.R. I232, I8r3, 6951, 8070

RMPR I80 (Color Pigments) 8 F.R. 6053, 8842, I0432

MPR 390 (Household Soaps and Cleansers Sold by Retail Food Stores) 8 F.R. 6428, 8947,9380

MPR 39I (Household Soaps and Cleansers Sold by Manufacturers and Certain Wholesalers) 8 F.R. 6435

RPS 63 (Retail Prices for New Rubber Tires and Tubes) 8 F.R. 2x10, 2663, 4332, 5746, 7597

RPS 66 (Retreaded and Recapped Rubber Tires) 7 F.R. 8803, 8948, 8 F.R. 3174, 738I

MPR 107 (Used Tires and Tubes) 7 F.R. I838, r981, 2394, 3891, 5177, 7365, 8586, 87.99, 8802, 8949, 8 F.R. 1584,2206

MPR I 43 (Wholesale Prices for New Rubber Tires and Tubes) 8 F.R. 4326, 5746

MPR I (Second-Hand Machine Tools) 8 F.R. Iori6

MPR 133 (Retail Prices for Farm Equipment) 7 F.R. 3185, 6936, 7599, 8948, 8 F.R. I34, 2286, I0503

MPR I36 (Machines and Parts and Machinery Services) 7 F.R. 5047

RPS 7 (Combed Cotton Yarns and the Processing Thereof) 7 F.R. I221, 2000, 2132, $2277,2393,2509,2737,3160,355 x, 3664,5481,8948,9732$, 10469, 8 F.R. 972, 5755, 9285

MPR 33 (Carded Cotton Yarns and the Processing Thereof) 7 F.R. 7557, 8948, roo70, 8 F.R. $2345,3526,975^{\circ}$

RPS 89 (Bed Linens) 7 F.R. 2107, 2000, 2132, 2299, 2739, 3163, 3327, 3447, 3962, 4I76, $4732,7599,8937,8948,8$ F.R. 8070 , I 245 . 